\title{
Acquisition of isotopic composition for surface snow in East Antarctica and the links to climatic parameters
}

\author{
Alexandra Touzeau ${ }^{1}$, Amaëlle Landais ${ }^{1}$, Barbara Stenni ${ }^{2}$, Ryu Uemura ${ }^{3}$, Kotaro Fukui $^{4}$, Shuji Fujita ${ }^{5,6}$, \\ Sarah Guilbaud $^{7}$, Alexey Ekaykin ${ }^{8,9}$, Mathieu Casado ${ }^{1}$, Eugeni Barkan $^{10}$, Boaz Luz $^{10}$, Olivier Magand ${ }^{11}$, \\ Grégory Teste $^{11}$, Emmanuel Le Meur ${ }^{11}$, Mélanie Baroni ${ }^{12}$, Joël Savarino ${ }^{11}$, Ilann Bourgeois ${ }^{13}$, and Camille Risi ${ }^{14}$ \\ ${ }^{1}$ LSCE - UMR CEA-CNRS-UVSQ-Université Paris Saclay, 8212-IPSL, Gif-sur-Yvette, France \\ ${ }^{2}$ DAIS, Ca'Foscari University of Venice, Venice, Italy \\ ${ }^{3}$ Faculty of Science, University of the Ryukyus, Okinawa, Japan \\ ${ }^{4}$ Tateyama Caldera Sabo Museum, Toyama, Japan \\ ${ }^{5}$ National Institute of Polar Research, Research Organization of Information and Systems, Tokyo, Japan \\ ${ }^{6}$ Department of Polar Science, The Graduate University for Advanced Studies (SOKENDAI), Tokyo, Japan \\ ${ }^{7}$ LPCA, Université du Littoral Côte d'Opale, Dunkirk, France \\ ${ }^{8}$ Arctic and Antarctic Research Institute, St. Petersburg, Russia \\ ${ }^{9}$ Saint Petersburg State University, St. Petersburg, Russia \\ ${ }^{10}$ Institute of Earth Sciences, Hebrew University of Jerusalem, Jerusalem, Israel \\ ${ }^{11}$ Univ. Grenoble Alpes/CNRS, Laboratoire de Glaciologie et Géophysique de l'Environnement (LGGE), \\ 38041 Grenoble, France \\ ${ }^{12}$ LECA, UMR5553 - CNRS-UJF, Université Joseph Fourier, Grenoble, France \\ ${ }^{13}$ Aix-Marseille Université, CNRS, IRD, CEREGE - UM34, 13545 Aix-en-Provence, France \\ ${ }^{14}$ Laboratoire de Météorologie Dynamique, Paris, France
}

Correspondence to: Alexandra Touzeau (alexandra.touzeau@1sce.ipsl.fr)

Received: 19 October 2015 - Published in The Cryosphere Discuss.: 18 November 2015

Revised: 1 March 2016 - Accepted: 30 March 2016 - Published: 15 April 2016

\begin{abstract}
The isotopic compositions of oxygen and hydrogen in ice cores are invaluable tools for the reconstruction of past climate variations. Used alone, they give insights into the variations of the local temperature, whereas taken together they can provide information on the climatic conditions at the point of origin of the moisture. However, recent analyses of snow from shallow pits indicate that the climatic signal can become erased in very low accumulation regions, due to local processes of snow reworking. The signal-to-noise ratio decreases and the climatic signal can then only be retrieved using stacks of several snow pits. Obviously, the signal is not completely lost at this stage, otherwise it would be impossible to extract valuable climate information from ice cores as has been done, for instance, for the last glaciation. To better understand how the climatic signal is passed from the precipitation to the snow, we present here results from varied snow samples from East Antarctica. First, we look
\end{abstract}

at the relationship between isotopes and temperature from a geographical point of view, using results from three traverses across Antarctica, to see how the relationship is built up through the distillation process. We also take advantage of these measures to see how second-order parameters (dexcess and ${ }^{17} \mathrm{O}$-excess) are related to $\delta^{18} \mathrm{O}$ and how they are controlled. d-excess increases in the interior of the continent (i.e., when $\delta^{18} \mathrm{O}$ decreases), due to the distillation process, whereas ${ }^{17} \mathrm{O}$-excess decreases in remote areas, due to kinetic fractionation at low temperature. In both cases, these changes are associated with the loss of original information regarding the source. Then, we look at the same relationships in precipitation samples collected over 1 year at Dome C and Vostok, as well as in surface snow at Dome C. We note that the slope of the $\delta^{18} \mathrm{O}$ vs. temperature $(T)$ relationship decreases in these samples compared to those from the traverses, and thus caution is advocated when using spatial slopes for past 
climate reconstruction. The second-order parameters behave in the same way in the precipitation as in the surface snow from traverses, indicating that similar processes are active and that their interpretation in terms of source climatic parameters is strongly complicated by local temperature effects in East Antarctica. Finally we check if the same relationships between $\delta^{18} \mathrm{O}$ and second-order parameters are also found in the snow from four snow pits. While the d-excess remains opposed to $\delta^{18} \mathrm{O}$ in most snow pits, the ${ }^{17} \mathrm{O}$-excess is no longer positively correlated to $\delta^{18} \mathrm{O}$ and even shows anticorrelation to $\delta^{18} \mathrm{O}$ at Vostok. This may be due to a stratospheric influence at this site and/or to post-deposition processes.

\section{Introduction}

Water isotopic composition of shallow and deep ice cores has long been used for reconstructing past climatic conditions in polar regions (Jouzel et al., 2007; Küttel et al., 2012; Schneider et al., 2006). The correlation between temperature and $\delta^{18} \mathrm{O}$ in polar regions is explained by the progressive relative loss of heavy isotopes with respect to the light ones during distillation of the water mass along its trajectory from warm to cold regions. However, more and more recent studies are evidencing that the water isotopic composition $\left(\delta^{18} \mathrm{O}\right.$ or $\delta \mathrm{D}$ ) in shallow snow pits in Antarctica does not follow the recent (last 50 years) temporal evolution of temperature, especially in regions of very low accumulation like the East Antarctic plateau (Ekaykin et al., 2002, 2004; Hoshina et al., 2014; Winkler et al., 2013). Post-depositional effects at the snow surface (Sokratov and Golubev, 2009) are responsible for a large noise, i.e., a non-climatic signal, in water isotopic records. This non-climatic signal can be shaped by many local effects such as surface relief, accumulation rate (Ekaykin et al., 2004) or temperature gradient in surface snow (Town et al., 2008). The situation is however improved when working on stacks of several shallow pits from which a climatic signal can be extracted (Altnau et al., 2015; Ekaykin et al., 2014; Schneider et al., 2006). In addition, the fact that $\delta^{18} \mathrm{O}$ or $\delta \mathrm{D}$ records in deep ice cores have been providing robust and high-resolution records of past temperature over the last glacial period clearly confirms the direct link between temperature and water isotopic composition of surface snow. Accordingly, either the post-depositional noise is not strong enough to entirely erase the original climatic signal, or some of the post-deposition processes are under the control of local temperature and thus reinstate a link between $\delta^{18} \mathrm{O}$ and temperature.

In addition to $\delta \mathrm{D}$ and $\delta^{18} \mathrm{O}$ records bringing information on temperature at first order, additional climatic information can be retrieved from second-order parameters like d-excess $\left(\mathrm{d}\right.$-excess $\left.=\delta \mathrm{D}-8 \cdot \delta^{18} \mathrm{O}\right)$ and ${ }^{17} \mathrm{O}$-excess $\left({ }^{17} \mathrm{O}\right.$ excess $\left.=\ln \left(\delta^{17} \mathrm{O}+1\right)-0.528 \cdot \ln \left(\delta^{18} \mathrm{O}+1\right)\right) \quad($ Dansgaard,
1964; Barkan and Luz, 2007; Landais et al., 2008). These parameters represent the $y$ intercepts of two straight lines, one relating $\delta \mathrm{D}$ and $\delta^{18} \mathrm{O}$ with a slope of 8 , and the other relating $\ln \left(\delta^{17} \mathrm{O}+1\right)$ and $\ln \left(\delta^{18} \mathrm{O}+1\right)$ with a slope of 0.528 . Most meteoric and surface waters over the globe fall on a line with a slope of 8 and a $y$ intercept of 10 in the $\delta \mathrm{D} / \delta^{18} \mathrm{O}$ diagram, called the Global Meteoric Water Line (Craig, 1961). However, variations of d-excess values have been observed in waters from various regions around the globe, and have been attributed, in the middle to low latitudes, to regional hydrological conditions (importance of evaporation and precipitation amount). When plotting the isotopic compositions of meteoric waters in a $\ln \left(\delta^{17} \mathrm{O}+1\right) / \ln \left(\delta^{18} \mathrm{O}+1\right)$ diagram, they fall on a straight line with a slope of 0.528 (Barkan and Luz, 2007; Landais et al., 2008; Luz and Barkan, 2010; Meijer and Li, 1998). Following the model of the d-excess definition, Barkan and Luz (2007) defined the ${ }^{17} \mathrm{O}$-excess in this diagram, and proposed that it was a tracer of climatic conditions at evaporation. The fact that $\delta^{18} \mathrm{O}$, d-excess and ${ }^{17} \mathrm{O}$-excess bear slightly different climatic information is due to influences of both equilibrium and kinetic fractionation processes on the water isotopic composition. Equilibrium and kinetic fractionation effects are induced by differences in saturation vapor pressure and diffusivities among isotopes, respectively. The different water isotopes exhibit different sensitivities to equilibrium and kinetic fractionation leading to variations in $\mathrm{d}$-excess and ${ }^{17} \mathrm{O}$-excess. At low latitudes, both $\mathrm{d}$-excess and ${ }^{17} \mathrm{O}$-excess will be sensitive to relative humidity during evaporation because of large variations in kinetic fractionation (Gat, 1996; Uemura et al., 2008, 2010). However, along the distillation process, the influence of relative humidity on d-excess is fading away to the benefit of the temperature gradient between the source and the precipitation site through equilibrium fractionation (Petit et al., 1991; Vimeux et al., 1999).

For coastal stations of Antarctica, ${ }^{17} \mathrm{O}$-excess and d-excess are markers of water origin, mainly temperature for d-excess (Delmotte et al., 2000; Kurita, 2011; Schlosser et al., 2008) and relative humidity for ${ }^{17} \mathrm{O}$-excess (Winkler et al., 2012). Presence of sea ice at the oceanic water evaporative regions may also contribute to the d-excess and ${ }^{17} \mathrm{O}$-excess signal (Gao et al., 2011; Schoenemann et al., 2014). However, at very low temperatures, and therefore in the central regions of Antarctica, the d-excess and ${ }^{17} \mathrm{O}$-excess in the precipitation become much more sensitive to the temperature of condensation than in the coastal regions. By using the different isotopic parameters, it remains possible to separate the influence of the source temperature from the influence of the local temperature, as was done in central Greenland (MassonDelmotte et al., 2005; Jouzel et al., 2005) and more recently in East Antarctica (Uemura et al., 2012) with a sensitivity of polar d-excess to source temperature of $1.5 \%{ }^{\circ} \mathrm{C}^{-1}$ (Risi et al., 2010) and a sensitivity of polar ${ }^{17} \mathrm{O}$-excess to source relative humidity of $-0.9 \mathrm{ppm} \%^{-1}$ (Landais et al., 2009). Because ${ }^{17} \mathrm{O}$-excess is less sensitive to temperature than $\mathrm{d}$ - 
excess, the site temperature influence on ${ }^{17} \mathrm{O}$-excess is only perceptible in very remote sites of East Antarctica (Winkler et al., 2012). Finally, ${ }^{17} \mathrm{O}$-excess may also bear the signature of stratospheric input since photochemical reactions involving ozone can affect the triple isotopic composition of oxygen in water in the stratosphere (Franz and Röckmann, 2005; Lin et al., 2013; Winkler et al., 2013; Zahn et al., 2006). This effect is generally marginal since the amount of water vapor in the stratosphere is very small (a few ppm only). However, it can become significant in East Antarctica where surface humidity is very low (i.e., at Vostok, the average specific humidity value is $\sim 112 \mathrm{ppmv}$ and decreases to almost $0 \mathrm{ppmv}$ in winter; Ekaykin, 2003).

The goal of this study is to understand how a climatic and environmental signature can be imprinted in the water isotopic composition of surface snow in remote East Antarctica. Our strategy is to make an optimal use of the combination of all water stable isotopes $\left(\delta \mathrm{D}, \delta^{17} \mathrm{O}, \delta^{18} \mathrm{O}\right)$ in different types of snow on the Antarctic plateau (precipitation, surface snow, buried snow) to disentangle temperature, water cycle and stratospheric influences.

The outline of our study is the following. In Sect. 2, we present the spatial distribution of water isotopic composition averaged in the top $30 \mathrm{~cm}$ of surface snow in East Antarctica with a focus on the remote East Antarctic plateau. In Sect. 3, we present variations of isotopic composition of precipitation and surface snow on two drilling sites in East Antarctica (Dome C, Vostok). Section 4 is a multi-isotope compilation of new data on several snow pits in East Antarctica. Each section is organized in three subsections: a review of current knowledge, a description of new measurements and results and a discussion. The final discussion shows that the multi-isotopes approach at different sites with similar temperature and accumulation rate characteristics is a useful tool to identify the main drivers for the water isotopic variations observed on shallow ice cores and to test the origin of the $\delta^{18} \mathrm{O}$ variations classically interpreted in terms of past temperature changes.

\section{Spatial variations of d-excess vs. $\delta^{18} O$ and ${ }^{17} O$-excess vs. $\delta^{18} O$ in Antarctic transects}

\subsection{Review of current knowledge}

The measurements of water isotopic composition in Antarctic transects have first provided a spatial relationship of $0.8 \%{ }^{\circ} \mathrm{C}^{-1}$ between surface temperature and $\delta^{18} \mathrm{O}$ in snow (Lorius and Merlivat, 1977; Masson-Delmotte et al., 2008). Applications of this relationship for reconstructing past temperature from records of $\delta^{18} \mathrm{O}$ in ice cores have however revealed some limitations because of combined influences of the seasonality of precipitations, origin of moisture, variations in elevation or post-deposition effects (e.g., Charles et al., 1994; Fawcett et al., 1997; Hoshina et al., 2014; Jouzel et al., 2003; Krinner et al., 1997; Masson-Delmotte et al., 2012; Neumann et al., 2005). Changes in moisture source, postdeposition effects and ice condensation are associated with kinetic fractionation effects. As a consequence, ${ }^{17} \mathrm{O}$-excess and d-excess are useful tools to disentangle the different influences on water isotopic composition in ice cores and hence improve our knowledge of the $\delta^{18} \mathrm{O}$ vs. temperature relationship.

For quantitative interpretations, the isotopic measurements are also classically combined with simple isotopic models (such as Mixed Cloud Isotope Model, i.e., MCIM, Ciais and Jouzel, 1994) or more sophisticated general circulation models (GCMs) equipped with water isotopes (such as the model LMDZ-iso from the Laboratoire de Météorologie Dynamique of Paris, where $\mathrm{Z}$ stands for the zoom function of the model; Risi et al., 2010, 2013). The aim of such a modeldata approach is twofold. First, the comparison of data and a model on the present-day spatial repartition of water isotopic composition in Antarctica is essential for the validation of the implementation of water isotopes in the model. Second, the use of isotopic models is essential to quantitatively interpret the water isotopic records in deep ice cores and translate them into records of climatic parameters (e.g., local temperature).

The model-data comparison over polar transects enables the correct implementation of the relative influences of kinetic vs. equilibrium fractionation processes during snow formation. These different influences are balanced through the expression of the supersaturation function, $S$, in the formulation of the fractionation coefficient $\left(\alpha_{V-S}\right)$ during snow formation so that

$\alpha_{V-S}=\frac{S}{(S-1) D / D^{*}+1 / \alpha_{\mathrm{eq}}}$,

where $\alpha_{\text {eq }}$ is the fractionation coefficient at equilibrium between vapor and solid; $D$ and $D^{*}$ are the diffusion coefficients of the light and heavy water isotopes in air. In the classical approach, $S$ is related to inversion temperature, $T$ in ${ }^{\circ} \mathrm{C}$, at which precipitation is assumed to form, so that $S=1-a T$ (Ciais and Jouzel, 1994; Jouzel and Merlivat, 1984). The relationship between supersaturation and temperature is not well constrained from atmospheric data. The classical way to adjust the slope $a$ in the different models is to compare water isotopes data and model outputs in polar regions. More precisely, because d-excess is very sensitive to kinetic effects at condensation in cold polar regions, the tuning of the supersaturation relationship to temperature is performed so that the observed relationship between $\delta^{18} \mathrm{O}$ and d-excess in Antarctica can be reproduced by the model (Ciais and Jouzel, 1994; Risi et al., 2013; Schmidt et al., 2007). In GCMs, this tuning leads to values for $a$ between 0.003 and 0.005 , with recent models (Risi et al., 2010; Lee et al., 2007; Schmidt et al., 2005; Tindall et al., 2009; Werner et al., 2011) favoring values equal to or greater than 0.004 . Using the link between ${ }^{17} \mathrm{O}$-excess and $\delta^{18} \mathrm{O}$ on polar transects is an additional con- 
straint (Landais et al., 2008; Pang et al., 2015). The best fit of an MCIM model to the isotopic compositions (d-excess and ${ }^{17} \mathrm{O}$-excess) measured on the Terra Nova Bay-Dome $\mathrm{C}$ traverse, is obtained with a value for $a$ of 0.0033 (Winkler et al., 2012). Pang et al. (2015) used the same value to fit to the Zhongshan-Dome A traverse. Adequate tuning of supersaturation is the key to quantitatively interpret the influence of temperature and moisture origin on $\delta^{18} \mathrm{O}$, d-excess and ${ }^{17} \mathrm{O}$ excess, especially in deep ice core records (Masson-Delmotte et al., 2005; Stenni et al., 2010; Winkler et al., 2012).

The longest ice core records (Dome C, Dome F, and Vostok) are located in the cold and dry regions of East Antarctica (EPICA comm. members, 2004; Kawamura et al., 2007; Petit et al., 1999). In these cold regions, the kinetic fractionation is very strong because of a high supersaturation level. The influence of kinetic fractionation on water isotopic composition is even stronger in glacial climatic conditions. In order to quantitatively interpret these glacial isotopic records, the expression of kinetic fractionation during snow formation should be known precisely at very low temperatures. Unfortunately, there are barely any present-day analogs for the glacial conditions encountered at Dome F, Vostok and Dome C. To better document the water isotopic composition of snow in extremely cold regions of Antarctica, and to improve the tuning of the supersaturation function, recent transects have been performed toward remote regions of the East Antarctic plateau (e.g., Becagli et al., 2004; Fujita et al., 2011; Masson-Delmotte et al., 2008; Mayewski and Goodwin, 1999; Pang et al., 2015).

\subsection{Measurements and results}

We present here a compilation of existing and new transect data combining the measurements of all water stable isotopes $\left(\delta^{18} \mathrm{O}\right.$, d-excess and ${ }^{17} \mathrm{O}$-excess $)$. The first transect combining these surface measurements was obtained within the ITASE project (Magand et al., 2004; Mayewski and Goodwin, 1999; Mayewski et al., 2005) between Terra Nova Bay and Dome C (Fig. 1), and water isotopic data were already published (Landais et al., 2008; Proposito et al., 2002). The second transect was performed between Zhongshan station and Dome A (Fig. 1) during the CHINARE expedition and water isotopic data were published in Pang et al. (2015). Finally, we present new water isotopic records from a transect obtained between Syowa, Dome Fuji and the site of the Drönning Maud Land ice core (EPICA DML, obtained within the European Project for Ice Coring in Antarctica, EPICA) (Fig. 1) through a Swedish-Japanese project (Fujita et al., 2011).

The surface snow samples were obtained from shallow pits on which the average water isotopic composition was measured. These pits had a depth of $1 \mathrm{~m}$ for the Terra Nova Bay-Dome C traverse (Proposito et al., 2002; Magand et al., 2004), $10 \mathrm{~cm}$ for the Zhongshang-Dome A traverse (Pang et al., 2015) and 10 to $30 \mathrm{~cm}$ for the Syowa-Dome F traverse.

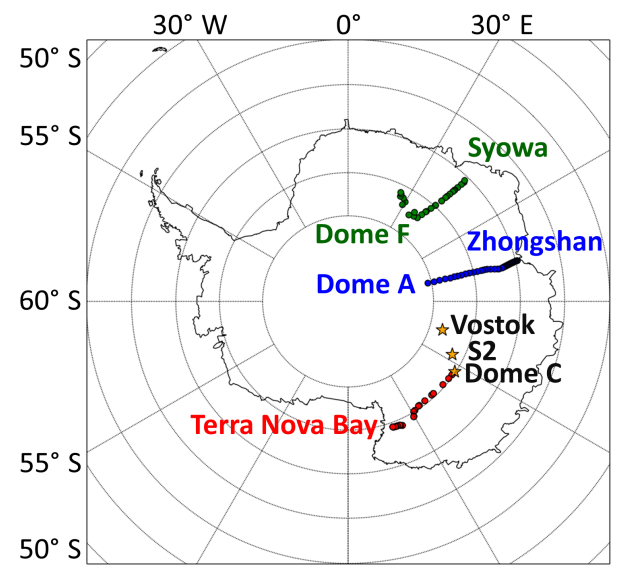

Figure 1. Map of the sites discussed in this manuscript.

Because the accumulation decreases from the coast towards the inland sites, the recorded period, for the first transect, varies from 2 years near the coast to 12 years at Dome C. For the Chinese traverse, the recorded period varies from 1 year in inland areas to 3 months in coastal areas. For the Syowa-Dome $\mathrm{F}$ traverse, the pits were shallower at inland sites $(10 \mathrm{~cm})$ and deeper at coastal sites in order to record at least 1 year in each sample. For the three transects presented here, ${ }^{17} \mathrm{O}$-excess measurements were obtained by fluorination method of water to oxygen (Barkan and Luz, 2005) followed by dual inlet measurements of produced oxygen vs. a reference oxygen standard. Measurements of the Terra Nova Bay-Dome C transect were performed at the Hebrew University of Jerusalem Israël (HUJI) using a Delta V mass spectrometer. Measurements of the two other transects were performed in France at the Climate and Environment Sciences Laboratory (LSCE) on a MAT 253 instrument. The measurements were calibrated vs. VSMOW (Vienna Standard Mean Ocean Water) and SLAP (Standard Light Antarctic Precipitation), taking reference values for $\delta^{18} \mathrm{O}$ and ${ }^{17} \mathrm{O}$-excess of respectively $0 \%$ and $0 \mathrm{ppm}$ (or per meg) and $-55.5 \%$ and 0 ppm (Pang et al., 2015; Schoenemann et al., 2013; Winkler et al., 2012). The pooled standard deviation $(1 \sigma)$ was computed from duplicate injection, fluorination and isotope ratio mass spectrometry (IRMS) measurements of the same sample, and is on average of $5-6 \mathrm{ppm}$ for ${ }^{17} \mathrm{O}$-excess. The $\delta^{18} \mathrm{O}$ and d-excess measurements for the Syowa-Dome Fuji transect were performed using an equilibration method (Uemura et al., 2007) at the National Institute of Polar Research, Japan.

All three transects show similar evolutions for the relationships between d-excess and $\delta^{18} \mathrm{O}$ on the one hand, and ${ }^{17} \mathrm{O}$ excess vs. $\delta^{18} \mathrm{O}$ on the other hand (Fig. 2, Table 2). For $\delta^{18} \mathrm{O}$ level lower than $-40 \%$, d-excess decreases for increasing $\delta^{18} \mathrm{O}$ with a slope of $-0.95 \% \% \%{ }^{-1} \cdot{ }^{17} \mathrm{O}$-excess does not exhibit a significant trend if we restrict the data in the range of $\delta^{18} \mathrm{O}>-50 \%$ as in the Terra Nova Bay-Dome C transect 
- Zhongshan - Dome A (Pang et al., 2015)

- Syowa - Dome F (unpublished data - coll. Ryu Uemura)

- Terra Nova Bay - Dome C (Landais et al., 2008)

MCIM with S=1-0.004T from Landais et al., 2012a

MCIM with $S=1-0.002 T$ from Landais et al., 2012a

......... LMDZ-iso with $\mathrm{S}=1-0.004 \mathrm{~T}$ from Risi et al., 2013

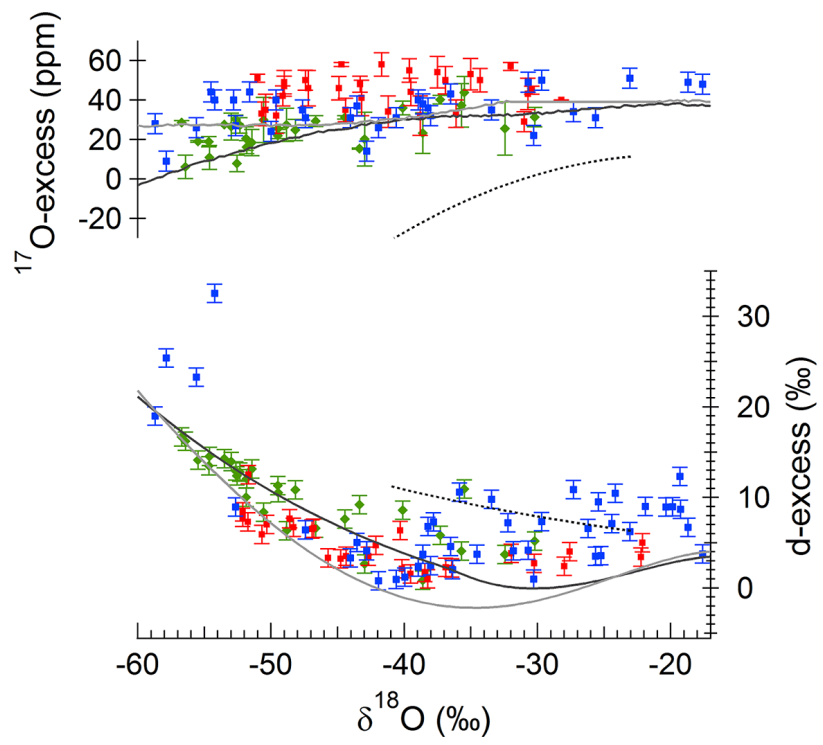

Figure 2. Water isotopic composition along Antarctic transects (blue: Zhongshan-Dome A transect; green: Syowa-Dome F transect; red: Terra Nova Bay-Dome C transect) and comparison with modeling outputs (black and grey line: MCIM with $S=1-0.004 T$ and $S=1-0.002 T$ respectively, from Landais et al., 2012a; dotted line: LMDZ-iso with $S=1-0.004 T$; Risi et al., 2013).

(Fig. 2, Table 2). For $\delta^{18} \mathrm{O}$ values lower than $-40 \%$, ${ }^{17} \mathrm{O}-$ excess increases with $\delta^{18} \mathrm{O}$ with a slope of $0.91 \mathrm{ppm} \% \mathrm{o}^{-1}$ (Table 2).

\subsection{Discussion}

For $\delta^{18} \mathrm{O}$ values between -20 and $-40 \%$, there is a large scattering of the d-excess values, with no clear trend. This can be due to a variability of the climatic conditions (temperature and relative humidity) at the source. For $\delta^{18} \mathrm{O}$ values below $-40 \%$, d-excess values are clearly anti-correlated with the $\delta^{18} \mathrm{O}$ values and change from $\sim 4 \%$ o to about $25 \%$. Such a change cannot be due to a change of the relative humidity of the source nor to a change of the source temperature that could explain only a few per mil changes. Thus, the increase of d-excess for decreasing $\delta^{18} \mathrm{O}$ values is probably caused by the fractionation at condensation during the distillation. This increase of d-excess is directly related to a decrease of the slope $\left(\mathrm{d} \delta \mathrm{D} / \mathrm{d} \delta^{18} \mathrm{O}\right)$ of the distillation line towards low $\delta^{18} \mathrm{O}$ values (i.e., low temperatures). Indeed, in the case of simple Rayleigh distillation, when the precipitated snow is immediately removed from the air mass and when only equilibrium fractionation occurs, we can express the local slope of the Rayleigh's distillation line at a given point as

$$
\frac{\mathrm{d} \delta \mathrm{D}}{\mathrm{d} \delta^{18} \mathrm{O}}=\frac{\left(\alpha_{V-S}^{D}-1\right)}{\left(\alpha_{V-S}^{18}-1\right)} \times \frac{(1+\delta \mathrm{D})}{\left(1+\delta^{18} \mathrm{O}\right)} .
$$

This slope expression comes from a simple mass balance associated with a condensation step, with a small amount of snow precipitated at equilibrium and thus removed from the vapor. No assumption is made on the previous distillation path. When considering only equilibrium, $\left(\alpha_{V-S}^{D}-1\right) /\left(\alpha_{V-S}^{18}-1\right)$ equals 8.7 at $0^{\circ} \mathrm{C}$ and then increases for lower temperature (it equals 10.1 at $-40^{\circ} \mathrm{C}$ ). However, when distillation increases, the ratio $(1+\delta \mathrm{D}) /\left(1+\delta^{18} \mathrm{O}\right)$ no longer equals 1 , and $1+\delta \mathrm{D}$ reaches values lower than 0.6 (corresponding to $\delta \mathrm{D}$ lower than $-400 \%$ ) in East Antarctica. The combined effect of distillation and equilibrium fractionation at low temperature leads to a slope of the meteoric water line smaller than 8 at about $-40^{\circ} \mathrm{C}$ (i.e., $0.6 \times 10.1$ is smaller than 8). The distillation effect is thus responsible for the decrease of the slope of the meteoric water line and hence the increase of d-excess for cold regions. Still, as explained in Jouzel and Merlivat (1984), the anti-correlation between $\mathrm{d}$-excess and $\delta^{18} \mathrm{O}$ is muted by the existence of the kinetic effect. Indeed, when considering also kinetic effects in addition to equilibrium during solid precipitation, $\left(\alpha_{V-S}^{D}-1\right) /\left(\alpha_{V-S}^{18}-1\right)$ equals 11.4 at $-40^{\circ} \mathrm{C}$. Still, the distillation effect dominates over the effect of both equilibrium and kinetic fractionation $(0.6 \times 11.4$ still remains smaller than 8 ) and the d-excess tends to increase toward low temperature.

The decrease of ${ }^{17} \mathrm{O}$-excess with decreasing temperature is not linked to distillation effect. Pure equilibrium fractionation in a Rayleigh distillation with similar dependencies of $\alpha_{V-S}^{17}$ and $\alpha_{V-S}^{18}$ to temperature (with $\left.\ln \left(\alpha_{V-S}^{17} / \alpha_{V-S}^{18}\right)=0.528\right)$ would lead to an increase of ${ }^{17} \mathrm{O}$ excess toward low temperatures (Landais et al., 2012b; Van Hook, 1968). Actually, the decrease of the ${ }^{17} \mathrm{O}$-excess toward low temperature is due to the kinetic effect at condensation. Indeed, the ratio $\ln \left(D / D^{17}\right) / \ln \left(D / D^{18}\right)$ is significantly lower $(0.518)$ than the corresponding ratio between equilibrium fractionation factors and it results in a decrease of the ${ }^{17} \mathrm{O}$-excess in a Rayleigh distillation system when kinetic effect at condensation is significant.

When the temperature decreases, the supersaturation in the air mass increases. This enhances the kinetic effect at condensation and leads to a decrease of both ${ }^{17} \mathrm{O}$-excess and $\mathrm{d}$ excess compared to their evolutions at pure equilibrium. In turn, the evolution of d-excess and ${ }^{17} \mathrm{O}$-excess at low temperature can help tuning the kinetic effect (Eq. 1) and especially the dependency of supersaturation to temperature. A change in the source region of the water vapor also influences ${ }^{17} \mathrm{O}$-excess and d-excess at low temperature, but cannot by itself explain the observed decrease in ${ }^{17} \mathrm{O}$-excess from about $30 \mathrm{ppm}$ to about $10 \mathrm{ppm}$ between $\delta^{18} \mathrm{O}$ values of -50 and 
$-60 \%$ (Fig. 2). Following Winkler et al. (2012) we estimate that the effect of relative humidity would not be more than $10 \mathrm{ppm}$ and the effect of a change of temperature, not more than $3 \mathrm{ppm}$.

The three transect data sets are of primary interest to constrain the fractionation formulation between vapor and snow in remote regions of Antarctica, as has already be done in previous publications (Landais et al., 2008; Pang et al., 2015; Winkler et al., 2012). We give here two examples for this tuning using published modeling experiments incorporating all stable water isotopes. Figure 2 shows that a good agreement can be obtained between isotopic data and modeling results when using a simple model of water trajectory (MCIM, Ciais and Jouzel, 1994; Landais et al., 2008) with an appropriate tuning of the supersaturation function ( $S=1-0.0033 T$ or $S=1-0.004 T$ according to the tuning of other parameters such as the temperature of solid condensation) (Landais et al., 2012a; Pang et al., 2015; Winkler et al., 2012). Winkler et al. (2012) discussed in details the tuning of the different parameters of the MCIM to be able to fit together $\delta^{18} \mathrm{O}$, d-excess and ${ }^{17} \mathrm{O}$-excess in central Antarctica and showed that supersaturation is indeed the key parameter to fit the relative evolution of ${ }^{17} \mathrm{O}$-excess vs. $\delta^{18} \mathrm{O}$ and d-excess vs. $\delta^{18} \mathrm{O}$. When supersaturation is too low (e.g., $S=1-0.002 T$ ), equilibrium fractionation dominates and modeled ${ }^{17} \mathrm{O}$-excess and d-excess are too high at low temperature (Fig. 2).

Things are more complicated when using AGCM equipped with water isotopes. Figure 2 shows that a d-excess increase and ${ }^{17} \mathrm{O}$-excess decrease for decreasing $\delta^{18} \mathrm{O}$ are also predicted by the LMDZ-iso model with an appropriate supersaturation function ( $S=1-0.004 T$, Risi et al., 2013). However, the modeled $\delta^{18} \mathrm{O}$ values are not low enough in Antarctica, thus leading to a strong discrepancy between the East Antarctica data sets and the modeling outputs. One of the main reasons for this disagreement is that temperatures in Antarctica are not cold enough in the LMDZ model. The overestimation of polar temperature is a common bias of CMIP5-PMIP3 simulations (e.g., Cauquoin et al., 2015b; Risi et al., 2010; Werner, 2011). This problem might be linked to the generally poor representation of the polar atmospheric boundary layer and related atmospheric inversion temperatures in GCMs (e.g., Krinner et al., 1997). Future improvements in the incorporation of the water isotopes in AGCM should take advantage of the transect data presented here.

Finally, the combined measurements of water isotopes along the three transects are essential to quantify the temperature influence on $\delta^{18} \mathrm{O}$, d-excess and ${ }^{17} \mathrm{O}$-excess. Using the supersaturation tuning on the transect data, Winkler et al. (2012) and Pang et al. (2015) found the following influences of temperature on $\delta^{18} \mathrm{O}$, $\mathrm{d}$-excess and ${ }^{17} \mathrm{O}$-excess in the remote drilling stations of East Antarctica (Dome A, Vostok, Dome C): $1 \% 0^{\circ} \mathrm{C}^{-1},-1.8 \%{ }^{\circ} \mathrm{C}^{-1}$ and $0.3 \mathrm{ppm}^{\circ} \mathrm{C}^{-1}$. These determinations are in agreement with the recent estimates by
Uemura et al. (2012) for the Dome F d-excess and $\delta^{18} \mathrm{O}$ sensitivity to temperature.

\section{Temporal variation of the water isotopic composition on the East Antarctic plateau}

\subsection{Introduction}

While the spatial relationship between $\delta^{18} \mathrm{O}$ and temperature has long been the reference to link $\delta^{18} \mathrm{O}$ records in ice cores to past temperature variations (Jouzel et al., 2013), numerous studies have shown the limitations of such an approach because climate influences $\delta^{18} \mathrm{O}$ in a complex way (see Sect. 2.1). One way to capture the uncertainty associated with such reconstruction is to evaluate the temporal dependency of $\delta^{18} \mathrm{O}$ to temperature. In this section, we thus estimate the relationship between temperature and water isotopes in precipitating snow over 1 year and the relationship between temperature and water isotopes in the surface snow on the same site. Because isotopic composition archived in ice core probably results both from the isotopic composition of the precipitation and from post-deposition effects, we study the annual relationship between the isotopic composition of snow and the temperature, both on precipitation samples and on surface snow sampled every week.

\subsection{Method}

Precipitation and surface snow samples come from two stations located on the East Antarctica plateau: Vostok and Dome C (Fig. 1). Climatological characteristics for these stations are listed in Table 1. Vostok and Dome $\mathrm{C}$ are both located on the East Antarctica plateau in low accumulation regions (2-3 cm ice eq $\mathrm{yr}^{-1}$, Table 1$)$. Vostok station is the most remote and highest station. In terms of temperature, Vostok experiences the coldest conditions, and the wind speed is greater at Vostok relative to Dome C (Table 1).

At Vostok, precipitation occurs in three forms: snow from clouds, diamond dust and rime. The durations of precipitation events vary from a few hours to a few days (the latter is typical for diamond dust). The Vostok precipitation sampling has been performed immediately after each precipitation event from December 1999 to December 2000 and can be separated into two data sets. The first one (series A) corresponds to sampling from a precipitation trap placed at $1 \mathrm{~m}$ above the snow surface and at $\sim 50 \mathrm{~m}$ windward from the station (Landais et al., 2012a). Samples collected in this trap consist of pure precipitation as ascertained by the calm weather conditions and absence of blowing snow at the time of collection. Sublimation in the trap is unlikely for two reasons. First, the high walls of the trap shaded the precipitation within it. Second, most of the samples were collected in winter, when insolation is minimal. The second series (B) corresponds to sampling from a lower precipitation trap buried with its upper edge at the snow surface. Thus the flow of 
Table 1. Main characteristics of the snow pits drilled in East Antarctica at three different stations. Meteorological data for Vostok from http://www.aari.ru. Data indicated by a * correspond to the snow pit Vostok_winkler (Winkler et al., 2013). Accumulation rate (S2) from E. Le Meur et al. (2016). Temperature at S2: L. Arnaud, personal communication, 2015, $10 \mathrm{~m}$ temperature at Dome C: J. Schwander, unpublished data, 2001. Wind speed at Dome C from the IPEV/PNRA project "Routine Meteorological Observations" at Concordia station http://www.climantartide.it.

\begin{tabular}{|c|c|c|c|}
\hline & Vostok & $\mathrm{S} 2$ & Dome C \\
\hline Latitude & $-78.5^{\circ} \mathrm{S}$ & $-76.3^{\circ} \mathrm{S}$ & $-75.1^{\circ} \mathrm{S}$ \\
\hline Elevation & $3488 \mathrm{~m}$ & $3229 \mathrm{~m}$ & $3233 \mathrm{~m}$ \\
\hline Mean annual air $T(2 \mathrm{~m})$ & $-55.2^{\circ} \mathrm{C}$ & NA & $-51.7^{\circ} \mathrm{C}$ \\
\hline Air $T$ coldest month & $-68.0^{\circ} \mathrm{C}(\mathrm{Aug})$ & NA & $-63.5^{\circ} \mathrm{C}(\mathrm{Jul})$. \\
\hline Air $T$ hottest month & $-31.8{ }^{\circ} \mathrm{C}(\mathrm{Dec})$ & NA & $-31.3^{\circ} \mathrm{C}(\mathrm{Jan})$ \\
\hline $10 \mathrm{~m}$ borehole $T$ & $-57^{\circ} \mathrm{C}$ & $-55.1^{\circ} \mathrm{C}$ & $-54.9^{\circ} \mathrm{C}$ \\
\hline Acc. rate (ice eq.) & $2.4 \mathrm{~cm} \mathrm{yr}^{-1}$ & $2.1 \mathrm{~cm} \mathrm{yr}^{-1}$ & $2.7 \mathrm{~cm} \mathrm{yr}^{-1}$ \\
\hline Wind speed & $5.1 \mathrm{~m} \mathrm{~s}^{-1}$ & NA & $3.3 \mathrm{~m} \mathrm{~s}^{-1}$ \\
\hline Average $\delta^{18} \mathrm{O}$ & $-57.13 \% o^{*} ;-57.06 \%$ o & $-53.81 \%$ & $-51.14 \%$ \\
\hline Average d-excess & $15.3 \% o^{*} ; 16.1 \% o$ & $12.3 \%$ & $9.1 \%$ \\
\hline Average ${ }^{17} \mathrm{O}$-excess & $10 \mathrm{ppm}^{*} ; 26 \mathrm{ppm}$ & $32 \mathrm{ppm}$ & $31 \mathrm{ppm}$ \\
\hline
\end{tabular}

(a) VOSTOK

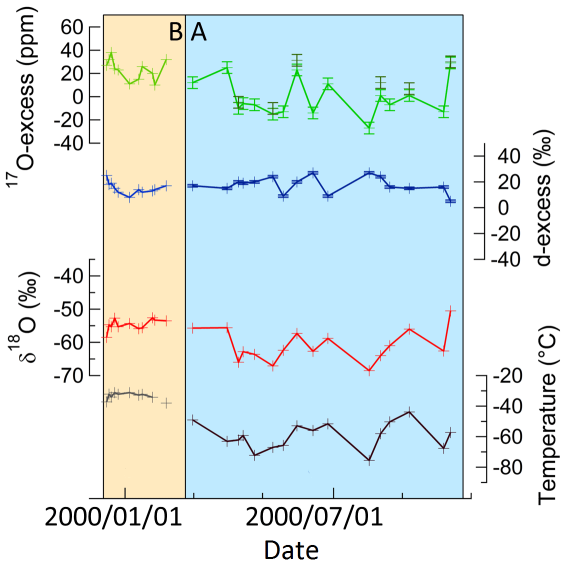

(b) DOME C

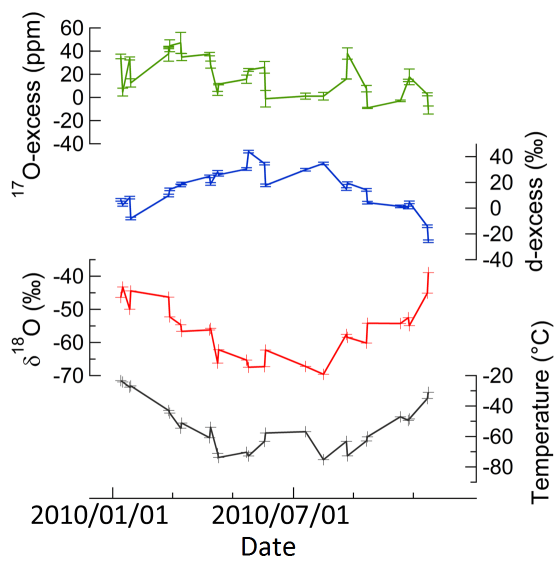

Figure 3. (a) Isotopic composition of the precipitation at Vostok over 1 year. A: samples from the upper trap (pure precipitation); B: samples from the lower trap (precipitation mixed with blowing snow). For the ${ }^{17} \mathrm{O}$-excess, dark green points were measured at LSCE, whereas light green points were measured at HUJI. (b) Isotopic composition of the precipitation at Dome C over 1 year.

blowing snow around the trap was unimpeded and the snow collected consists of a mixture of precipitation and blowing snow. After the collection, the samples from the two series were melted, poured into special plastic bottles and frozen again. This procedure was followed to avoid alteration of the initial isotopic composition of precipitation due to sublimation and exchange with the atmospheric water vapor. Sample volume varied between $1 \mathrm{~mL}$ (diamond dust) and 10-20 mL (heavy precipitation).

The $\delta \mathrm{D}, \delta^{8} \mathrm{O}$ and ${ }^{17} \mathrm{O}$-excess measurements for the 16 samples of series A (Fig. 3a, blue panel: February 2000-September 2000) have been published in Landais et al. (2012a). $\delta^{18} \mathrm{O}$ and d-excess measurements were performed at Geophysics department, Niels Bohr Institute, University of Copenhagen, while ${ }^{17} \mathrm{O}$-excess was measured at
HUJI using a Delta $\mathrm{V}$ instrument (duplicate measurements of ${ }^{17} \mathrm{O}$-excess were also realized at LSCE for six samples). The 11 samples of series B were measured in the same institutions as the samples of series A (Fig. 3a, yellow panel: December 1999-February 2000).

The Dome $\mathrm{C}$ precipitation sampling has been continuously performed since December 2007 in the framework of the Italian glaciology program at Concordia station. Almost 100 samples are collected every year and analyzed for $\delta \mathrm{D}$ and $\delta^{18} \mathrm{O}$. Here, we present only a subset of this sample collection from January to December 2010 (Fig. 3b). Unfortunately, samples from the year 2011 (period when the surface snow was sampled, see the last paragraph of this section) were not available. The ${ }^{17} \mathrm{O}$-excess was measured at LSCE using the fluorination method followed by dual inlet analy- 
sis on a MAT 253 as for the transect samples of the previous section (Sect. 2) and Vostok precipitation samples.

It should be noted that some $\delta^{18} \mathrm{O}$ values presented on Fig. 3 are significantly lower than the $\delta^{18} \mathrm{O}$ value of the SLAP $(-55.5 \%)$. The classical two-point calibration VSMOWSLAP is thus possibly not valid here. We have addressed the $\delta^{18} \mathrm{O}$ calibration issue for very low $\delta^{18} \mathrm{O}$ values by diluting well-characterized standards with almost pure $\mathrm{H}_{2}^{16} \mathrm{O}$ (Isotec Water-16O from Sigma-Aldrich; Casado et al., 2016). These dilutions and associated measurements have shown that the VSMOW-SLAP calibration for $\delta^{18} \mathrm{O}$ on our instrument can be extrapolated down to $-90 \%$. It was not possible to do the same exercise with ${ }^{17} \mathrm{O}$-excess because the water with almost pure $\mathrm{H}_{2}^{16} \mathrm{O}(99.98 \%$, Casado et al., 2016) was not characterized in $\mathrm{H}_{2}^{17} \mathrm{O}$ content. Still, measurements of much depleted $\delta^{18} \mathrm{O}$ samples on different mass spectrometers suggest that we may create biases of up to $10 \mathrm{ppm}$ in the ${ }^{17} \mathrm{O}$-excess values expressed in a VSMOW-SLAP scale. Mean ${ }^{17} \mathrm{O}$-excess values associated with $\delta^{18} \mathrm{O}<-55.5 \%$ and performed on different mass spectrometers may therefore not be directly comparable.

The sampling of surface snow at Dome $\mathrm{C}$ was performed between December 2010 and December 2011, in the clean area, about $1 \mathrm{~km}$ away from Concordia station, according to the following procedure. Each day of collection, an area of approximatively $5 \mathrm{~m}^{2}$ was chosen (different from the previous one) and snow is scraped from 5 to 10 spots $\left(\sim 0.04 \mathrm{~m}^{2}\right)$ within this area. This variability is due to the necessity to collect enough snow for later analysis. Only the first $1-2 \mathrm{~mm}$ of snow was collected, using a metal blade. The snow collected was homogenized and melted, and a fraction destined for isotopic analysis transferred into a $20 \mathrm{~mL}$ vial and then kept frozen until analysis. In every $5 \mathrm{~m}^{2}$ area, sastrugi were avoided, but otherwise (i.e., in flat areas) the sampling was performed randomly and no distinction was made between snow types; drifted snow, wind crust, soft, hard and hoar snow are sampled indiscriminately. The aim was to sample all types of snow present during the day of sampling to access the average composition of the surface snow in direct contact with the atmosphere. On this set of samples, $\delta^{18} \mathrm{O}$ and $\delta \mathrm{D}$ were measured by a wavelength scanned cavity ringdown spectroscopy instrument (Picarro L2130i) with a resulting uncertainty of $1 \sigma=0.05 \%$ for $\delta^{18} \mathrm{O}$ and $0.5 \%$ for $\delta \mathrm{D}$. As for the other new ${ }^{17} \mathrm{O}$-excess data presented in this manuscript, we used here the fluorination method coupled with dual inlet mass spectrometry (MAT 253) with a resulting uncertainty $1 \sigma=5 \mathrm{ppm}$.

\subsection{Discussion}

As already observed for other Antarctic sites where $\delta^{18} \mathrm{O}$ measurements on precipitation samples have been performed, $\delta^{18} \mathrm{O}$ of falling snow is strongly related to temperature both at Dome C $(R=0.88, p<0.05$, Table 2$)$ and at Vostok $(R=0.77, p<0.05$, Table 2$)$. The annual slope of

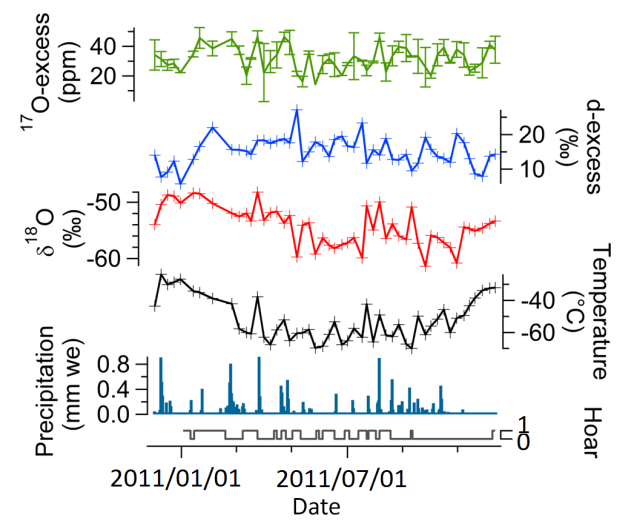

Figure 4. Isotopic composition of surface snow sampled every 12 weeks at Dome C.

$\delta^{18} \mathrm{O}$ vs. temperature is 0.46 and $0.26 \% 0^{\circ} \mathrm{C}^{-1}$ at Dome $\mathrm{C}$ and Vostok respectively (Table 2). The annual slope at Dome $\mathrm{C}$ is comparable to the one observed at Dome $\mathrm{F}$ for a similar temperature level $\left(0.47\right.$ to $0.78 \%{ }^{\circ} \mathrm{C}^{-1}$, Fujita and Abe, 2006; Motoyama et al., 2005), while the Vostok seasonal $\delta^{18} \mathrm{O}$ vs. temperature slope is significantly lower. Using only the samples of series $A$ (instead of $A+B$ ) increases the annual slope at Vostok slightly $\left(0.35 \% 0^{\circ} \mathrm{C}^{-1}\right)$, suggesting that this low slope can result from post-deposition noise (i.e., blowing snow with an isotopic composition different from the one of the falling snow). Several other possible explanations have already been evoked to explain this low slope (Ekaykin, 2003; Landais et al., 2012a), such as a strong gradient between condensation and surface temperature at Vostok when precipitation occurred, or a change in the type of precipitation at Vostok (possible high contribution of diamond dust in precipitation). However, we should also note that at Vostok, we have only a small number of water samples corresponding to precipitation events associated with the largest amount of snow. These large precipitation events are associated with relatively high temperature in winter. Such a selection of particular precipitation events may also have an influence on the final $\delta^{18} \mathrm{O}$ vs. temperature slope; therefore we avoid speculating on this particular value with so few data points (26 at Vostok).

As for the surface snow at Dome $\mathrm{C}$, there is a rather good correlation between $\delta^{18} \mathrm{O}$ and $2 \mathrm{~m}$ air temperature (Fig. 4) with a global slope of $0.14 \%{ }^{\circ} \mathrm{C}^{-1}(R=0.54, p<0.05$, Table 2). This slope is lower than the annual slope in the precipitation at Dome $\mathrm{C}\left(0.46 \%{ }^{\circ} \mathrm{C}^{-1}, R=0.88, p<0.05\right.$, Table 2) and hence much lower than the spatial slope. The fact that temporal slopes are smaller than the spatial ones has to be kept in mind when applying these slopes to past temperature reconstructions. When looking in more detail at the evolution of $\delta^{18} \mathrm{O}$ over 1 year, two observations can be made. First, between December 2010 and March 2011, we observe a long-term decreasing trend of both temperature and surface snow $\delta^{18} \mathrm{O}$, in a period associated with only rare precipita- 


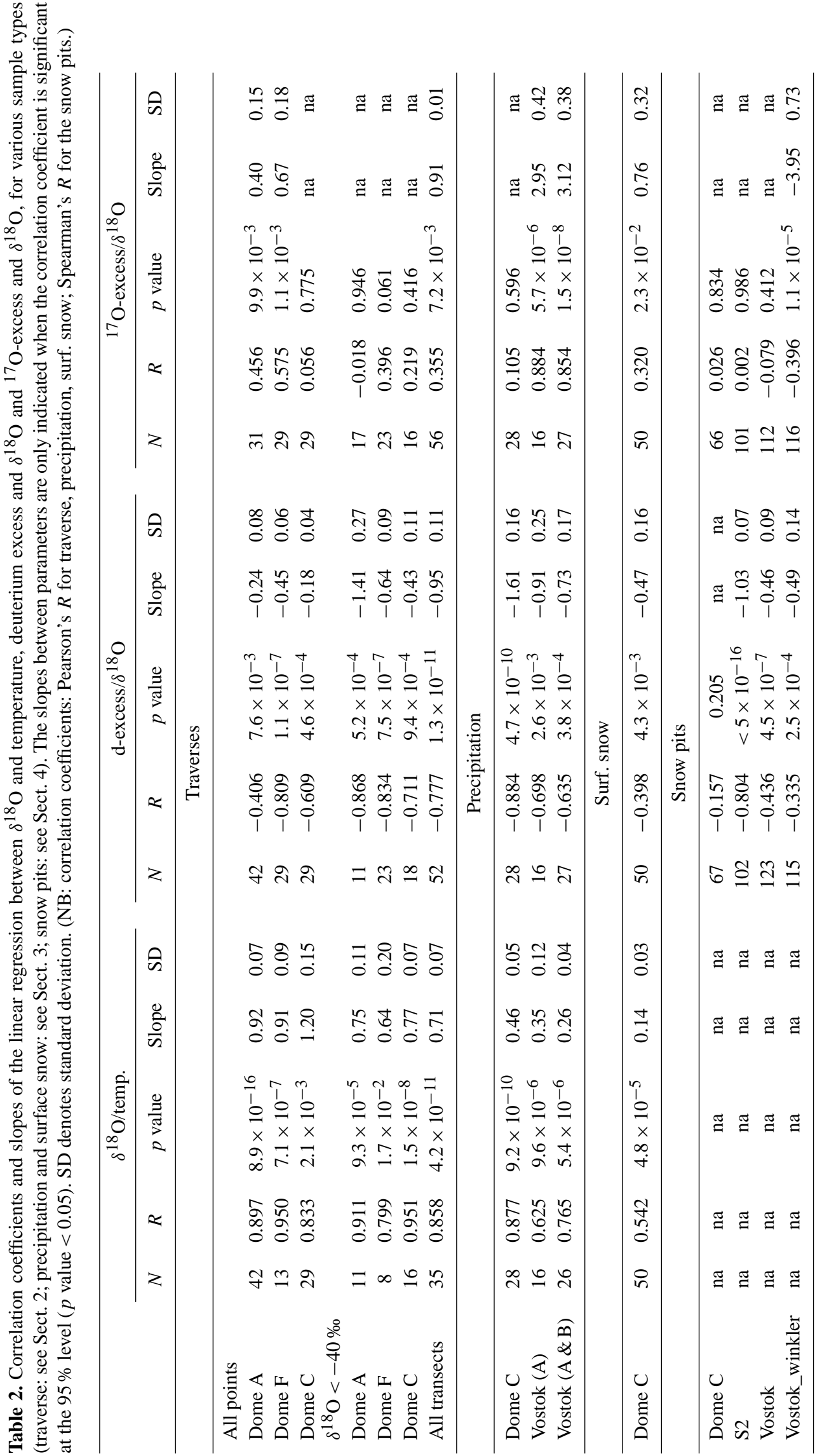


tions events. Here the number of points is limited and this correlation should be checked by a higher resolution study. A possible explanation for the joint evolution of these two parameters (between precipitation events) would be surface snow metamorphism and exchange with the atmospheric water vapor, as already evidenced in Greenland (Casado et al., 2016; Ritter et al., 2016; Steen-Larsen et al., 2013). This mechanism is supported by the synchronous prolonged period of hoar formation (Fig. 4), surface hoar crystals being the product of water vapor condensation (Champollion et al., 2013). Besides, the porous surface hoar could also act as a trap for the rare snow particles and diamond dust (Champollion et al., 2013), therefore facilitating the evolution of the isotopic composition of the snow in the absence of precipitation events. Second, several short warming events during winter 2011 are also clearly imprinted in the $\delta^{18} \mathrm{O}$ signal. Because warm events are often associated with precipitation events (Fig. 4), the temperature- $\delta^{18} \mathrm{O}$ link during these events can result from fresh snow deposition. Note that the warm event of mid-June (17 June) is not reflected in the $\delta^{18} \mathrm{O}$ signal. This may be due to wind erosion and redeposition of the snow.

The relationship between d-excess or ${ }^{17} \mathrm{O}$-excess and $\delta^{18} \mathrm{O}$ can also help us to understand the annual variation of the isotopic composition of the snow. Here the annual amplitude of variation (10-20\%o for d-excess and 30-40 ppm for ${ }^{17} \mathrm{O}$ excess) suggests that the main control is the site temperature, because other parameters such as source temperature and relative humidity would not account for more than a few per mil for d-excess or more than $10 \mathrm{ppm}$ for ${ }^{17} \mathrm{O}$-excess (Winkler et al., 2012). Both for Vostok and Dome C precipitation, d-excess and $\delta^{18} \mathrm{O}$ are anti-correlated with a slope of $-1.61 \% \%^{-1}(R=-0.88, p<0.05$, Table 2$)$ at Dome C and -0.7 at Vostok $(R=-0.64, p<0.05$, Table 2$)$. Even if there is a large difference between the two slopes, this anticorrelation is expected and has already been observed with similar values $\left(1\right.$ to $2 \% \circ \% o^{-1}$ ) on the transect data: for $\delta^{18} \mathrm{O}$ level below $-40 \%$, we observe a clear anti-correlation between $\delta^{18} \mathrm{O}$ and d-excess linked to the effect of distillation. In the surface snow at Dome $\mathrm{C}$, d-excess is also globally anticorrelated with $\delta^{18} \mathrm{O}$ over the whole year 2011 with a slope of $-0.47 \% \circ \% o^{-1}(R=-0.4, p<0.05$, Table 2$)$, indicating that the effect of the distillation process is still perceptible in the surface snow but somehow obscured by another process.

${ }^{17} \mathrm{O}$-excess of precipitation is significantly correlated with $\delta^{18} \mathrm{O}$ at Vostok (2.95 ppm $\%{ }^{-1}, R=0.88, p<0.05$, Table 2) with a higher slope and correlation coefficient compared to the transect data set with $\delta^{18} \mathrm{O}<-40 \%$ o $\left(0.91 \mathrm{ppm} \%{ }^{-1}\right.$, $R=0.36, p<0.05$, Table 2). On the opposite, no clear relationship can be drawn from the ${ }^{17} \mathrm{O}$-excess vs. $\delta^{18} \mathrm{O}$ values in the precipitation at Dome $\mathrm{C}$, even if sampling at both sites encompasses the same range of $\delta^{18} \mathrm{O}$ values down to $-70 \%$ and surface temperature down to $-75^{\circ} \mathrm{C}$. Such a result suggests that the kinetic effect during condensation is not the only driver for ${ }^{17} \mathrm{O}$-excess variations in East Antarctica.
The analysis of the surface snow at Dome $\mathrm{C}$, however, shows a small (but significant) correlation between ${ }^{17} \mathrm{O}$-excess and $\delta^{18} \mathrm{O}$. How can this correlation exist in the surface snow and not (significantly) in the precipitation at the same site? We propose two hypotheses regarding this phenomenon. First, at Dome $C$ the annual cycle of temperature in 2010 is very well defined and does not show the frequent warming events (up to $-50{ }^{\circ} \mathrm{C}$ ) observed during the winter of 2011 at Dome $\mathrm{C}$ and in 2000 at Vostok. In other words, natural variability may be the cause of these differences, with winter 2010 experiencing more stable (and therefore colder) conditions than winter 2000 and 2011, and thus reduced correlation between ${ }^{17} \mathrm{O}$-excess and $\delta^{18} \mathrm{O}$. Alternatively, the post-deposition processes within the snow could be responsible for a renewed correlation between ${ }^{17} \mathrm{O}$-excess and $\delta^{18} \mathrm{O}$.

\section{Variability of water isotopic composition in snow pits}

\subsection{Description of the sampling sites}

The next step to understand the archiving of the water isotopic composition is to look at the combined water isotopes on short snow pits at different places in Antarctica. The isotopic composition on snow pits will indeed be influenced by the isotopic composition of snow precipitation, diamond dust deposition and post-deposition effects, involving exchanges with atmospheric water vapor. Many isotopic measurements have been performed on snow pits in Antarctica (e.g., Altnau et al., 2015; Ekaykin et al., 2014) but except the study from Winkler et al. (2013) focusing on one shallow pit only in Vostok, none of the previous studies have combined measurements of all stable water isotopes.

Here, we compare the results obtained from snow pits from three localities: Vostok, S2 and Dome C (Fig. 1). The main characteristics of the sampling sites are described in Table 1. From Dome C to S2, and then to Vostok, the temperature decreases, while the altitude increases. Thus the combination of the continental effect and of the altitudinal effect should lead to decreasing $\delta^{18} \mathrm{O}$ values, because of a more advanced distillation at the most remote sites. Interestingly, results from modeling of air parcel trajectories (Reijmer et al., 2002) indicate that air parcels moving toward Vostok pass over Dome $\mathrm{C}$, thus confirming the pathway of the distillation.

To see if the distillation is indeed the main process controlling the isotopic composition in the snow pits, we first compare the average values between the pits, and then look at the evolution of isotopic parameters. Given the accumulation rate, several decades are probably recorded (about 60 years). However, we avoid discussing any precise age scale for these shallow pits drilled in East Antarctica. Indeed, because of the low accumulation rate and redeposition effects in this region, the precise chronology is uncertain (possibility of gaps or snow layer repetition). This prevents a proper interpretation of isotopic variations in terms of interannual variability and 
we only discuss in the following the average isotopic values and correlation between the different isotopic parameters. If distillation is the main driver, we expect low $\delta^{18} \mathrm{O}$ values to be associated with high d-excess values, because they would be symptomatic of a more pronounced distillation, and with lower ${ }^{17} \mathrm{O}$-excess values, because of the kinetic effect at very low temperature.

\subsection{Isotopic measurements}

Here, we have analyzed the isotopic composition of the first (2 to 4) meters of snow at three localities: Vostok, S2 and Dome C (Fig. 1). At Vostok, we can compare new data from the snow pit obtained for this study to a snow pit previously analyzed in $\delta \mathrm{D}, \delta^{18} \mathrm{O}$ and $\delta^{17} \mathrm{O}$ (Winkler et al., 2013) that was dated to 1951 at $3.46 \mathrm{~m}$. In the following, this snow pit will be called Vostok_winkler. For the different snow pits, the snow was sampled every $3 \mathrm{~cm}$ from the top to the bottom. The new $\delta^{18} \mathrm{O}, \delta \mathrm{D}$ and ${ }^{17} \mathrm{O}$-excess measurements presented here were performed following the analytical methods of Sect. 2.2 with a MAT253, while the data from Vostok_winkler were measured on a Delta V.

\subsection{Results}

The average values for $\delta^{18} \mathrm{O}$ (Table 1) decrease from Dome $\mathrm{C}$ to Vostok. The average d-excess values have an opposite trend relative to the $\delta^{18} \mathrm{O}$ values (they increase from $9.1 \%$ at Dome C to $12.3 \%$ at S2 and to $16.1 \%$ at Vostok). Finally, the average ${ }^{17} \mathrm{O}$-excess values measured on the same instrument are similar at Dome C, S2 and Vostok $(\sim 30 \mathrm{ppm})$. Correlations between variations of $\delta^{18} \mathrm{O}$, d-excess and ${ }^{17} \mathrm{O}$ excess were inferred first for the whole isotopic series of the snow pits and then, for the couple $\delta^{18} \mathrm{O} /{ }^{17} \mathrm{O}$-excess for subsections of 20 points, corresponding to $60 \mathrm{~cm}$, or about 10 years. The Spearman's correlations performed over a shifting window of 20 points are significant (with $\alpha=0.05$ ) if the absolute value of the correlation coefficient $\rho$ is higher than 0.443 .

The results of Spearman's correlations for the whole series are presented in Table 2. For the d-excess $/ \delta^{18} \mathrm{O}$ couple of parameters, the correlation is negative in all the pits, and strongest at $\mathrm{S} 2$. We note that the correlation at Dome C is also negative but not significant at the 0.05 level. Regarding the ${ }^{17} \mathrm{O}$-excess $/ \delta^{18} \mathrm{O}$ couple of parameters, the correlation is significant only in the Vostok_winkler snow pit. At this site, the correlation is negative.

The shifting window correlation coefficients between ${ }^{17} \mathrm{O}$ excess and $\delta^{18} \mathrm{O}$ are overall negative at Vostok and $\mathrm{S} 2$ (Fig. 5a-c). They are significant in most of the core $(70 \%$ of cases) for Vostok_winkler, and also in a large part of the core for the second snow pit at Vostok (30\% of cases) and at S2 (40\% of cases). At Dome C, the correlation coefficients are small, and oscillate between positive and negative values (Fig. 5d). They only reach significant values in $4 \%$ of cases.
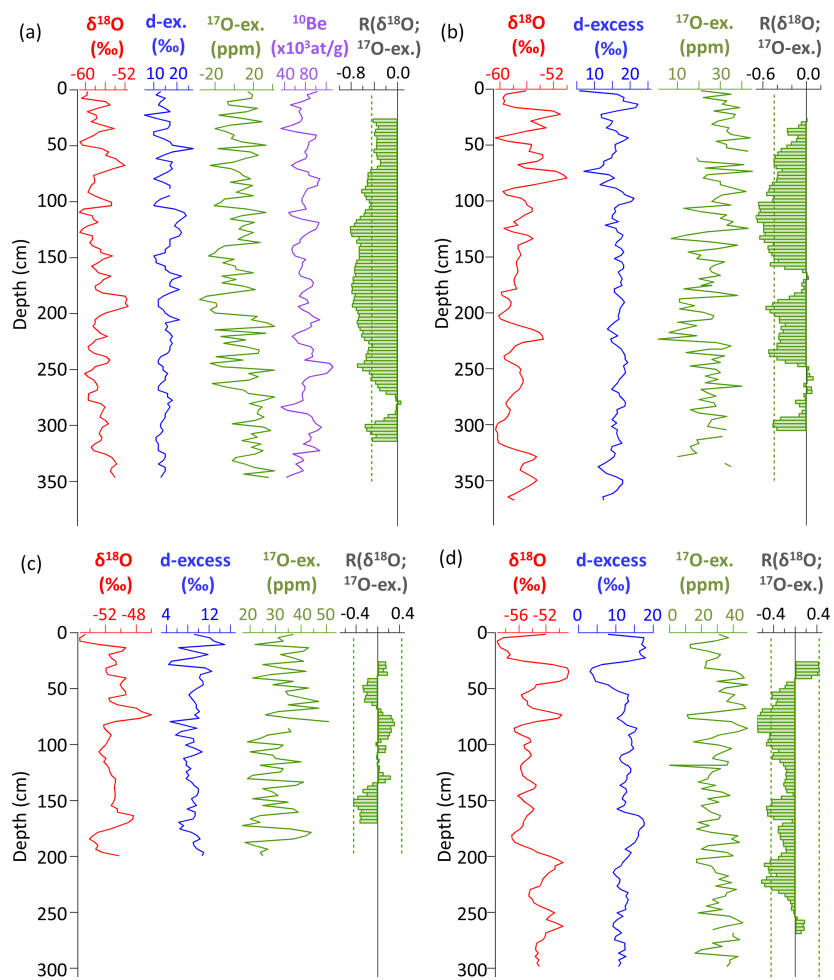

Figure 5. Water isotopic data from snow pits and correlation between $\delta^{18} \mathrm{O}$ and ${ }^{17} \mathrm{O}$-excess for Vostok_winkler ((a); Winkler et al., 2013), Vostok (b), Dome C (c) and S2 (d). Each correlation coefficient $R$ between $\delta^{18} \mathrm{O}$ and ${ }^{17} \mathrm{O}$-excess corresponds to a correlation realized over 20 points (see Sect. 4.3). The correlation coefficients are significant when they are larger than 0.443 in absolute values. The limit of significance is displayed as a green dotted line.

\subsection{Interpretation of the results and discussion of processes}

The comparison of the average values between sites is coherent with the distillation process, with $\delta^{18} \mathrm{O}$ values decreasing and d-excess values increasing from Dome $\mathrm{C}$ to Vostok. However, the kinetic effect at condensation is not clearly apparent, as the ${ }^{17} \mathrm{O}$-excess values remain more or less the same between the sites.

Global Spearman's correlations led to significant negative correlations between $\delta^{18} \mathrm{O}$ and d-excess for S2, Vostok and Vostok_winkler. These negative correlations are consistent with those already detected in the snow from transects and in the precipitation, and therefore with a distillation process. An effect of the source is also possible, but not sufficient to explain the large amplitude of variations in d-excess and ${ }^{17} \mathrm{O}$-excess $(10-20 \%$ for d-excess and $30-40 \mathrm{ppm}$ for ${ }^{17} \mathrm{O}$-excess). At Dome $\mathrm{C}$, the absence of significant correlation in the snow pit is unexpected, considering the anticorrelation observed at this site both in the precipitation and in the surface snow. Thus the distillation process at this site appears somehow obliterated by post-deposition processes 
(erosion, transport and redepositing of snow, diffusion of isotopes within the firn) affecting the isotopic compositions and their relationships.

The overall negative relationship between $\delta^{18} \mathrm{O}$ and ${ }^{17} \mathrm{O}$ excess at Vostok and S2 (considering not only the whole series values but also the subsections values) is rather intriguing. In effect, this is opposed to what has been observed on transects and at the seasonal scale for precipitation samples. The anti-correlation between ${ }^{17} \mathrm{O}$-excess and $\delta^{18} \mathrm{O}$ in these two sites definitively shows that distillation is not the driver of the ${ }^{17} \mathrm{O}$-excess variations in the East Antarctica snow pits. Other mechanisms must then be considered to account for such negative correlation. Winkler et al. (2013) have explored different possible explanations for the relationships between ${ }^{17} \mathrm{O}$-excess, $\delta^{18} \mathrm{O}$ and $\delta \mathrm{D}$. Using additional ${ }^{10} \mathrm{Be}$ measurements in the same pit at Vostok and the good correlation between ${ }^{10} \mathrm{Be}$ and ${ }^{17} \mathrm{O}$-excess, they have concluded that stratospheric input may be a good candidate for explaining the high ${ }^{17} \mathrm{O}$-excess values concomitant with high ${ }^{10} \mathrm{Be}$ and low $\delta^{18} \mathrm{O}$. Indeed, mass-independent fractionation associated with reaction with ozone in the stratosphere may lead to strong ${ }^{17} \mathrm{O}$-excess in the stratosphere (Zahn et al., 2006). Even if the amount of water vapor is very small there ( $2 \mathrm{ppm})$, East Antarctica is very dry (30 ppm at Vostok) and located under the influence of the polar vortex hence with significant stratospheric input (e.g., Cauquoin et al., 2015a; Stohl and Sodemann, 2010). We propose here that the more frequent anti-correlation between ${ }^{17} \mathrm{O}$-excess and $\delta^{18} \mathrm{O} \mathrm{ob}-$ served at Vostok relative to S2, and also at Vostok and S2 with respect to Dome C, is linked to a stronger influence of stratospheric input in areas that are more remote (i.e., Vostok and S2). This is supported by the highest level of natural tritium observed at Vostok (100 TU) compared to Dome C (30 TU) (Becagli et al., 2004; Fourré et al., 2006; Proposito et al., 2002). Natural tritium is indeed mainly produced by the interaction of cosmic radiations with the upper atmosphere (Craig and Lal, 1961; Masarik and Beer, 2009) and is thus a good marker of stratospheric water input when measured in surface snow. Unfortunately, no tritium measurement is available at $\mathrm{S} 2$ now.

Finally, note that post-deposition could also have an effect on the relationship between $\delta^{18} \mathrm{O}$, d-excess and ${ }^{17} \mathrm{O}$-excess. This effect has been studied in Winkler et al. (2013) who showed by simple calculations at steady state that this effect could be important. Still, this calculation could not explain the observed relationship at Vostok_winkler and particularly how the seasonal correlation between $\delta^{18} \mathrm{O}$ and ${ }^{17} \mathrm{O}$-excess observed in precipitation at Vostok can be changed to an anticorrelation in the snow. To better quantify this effect in East Antarctica, modeling of post-deposition effect should be improved by using a dynamic model as in Town et al. (2008) and by using field measurements and experiments to tune it to the East Antarctic plateau.

\section{Conclusions}

We presented a compilation of new water stable isotopic data in East Antarctica on surface snow, precipitation and snow pits. The comparison of the different stable isotope parameters $\delta^{18} \mathrm{O}$, d-excess and ${ }^{17} \mathrm{O}$-excess is very useful to decipher the various influences on the water isotopic composition in ice cores that is further archived in deep ice cores. We selected sites in East Antarctica with extreme climatic and isotopic values $\left(\delta^{18} \mathrm{O}\right.$ down to $-70 \%$ in winter) in order to obtain a present-day equivalent to the glacial period archived in deep ice cores. These sites are located at the very end of the distillation trajectory with possible significant input of stratospheric water vapor that has an influence on water isotopic ratios.

Table 2 presents the compilation of the relationships between the different isotopic parameters and temperature for the different types of snow and different locations. Measurements of water isotopes in average surface snow and precipitations show a systematic anti-correlation between d-excess and $\delta^{18} \mathrm{O}$ for $\delta^{18} \mathrm{O}$ lower than $-40 \%$ and, except at Dome C, a systematic correlation between ${ }^{17} \mathrm{O}$-excess and $\delta^{18} \mathrm{O}$ for $\delta^{18} \mathrm{O}$ lower than $-40 \%$. Even if the low $\delta^{18} \mathrm{O}$ values encountered in East Antarctica cannot yet be reproduced by AGCM equipped with water isotopes, the (anti-)correlation between water isotopic parameters can be explained well. The anticorrelation between d-excess and $\delta^{18} \mathrm{O}$ results from the distillation and the correlation between ${ }^{17} \mathrm{O}$-excess and $\delta^{18} \mathrm{O}$ at very low temperatures; this is the result of kinetic effects at condensation in a strongly supersaturated environment.

The links between isotopic parameters are however different in snow pits of East Antarctica. Especially, the positive relationship between $\delta^{18} \mathrm{O}$ and ${ }^{17} \mathrm{O}$-excess, associated with kinetic effects at low temperatures, is not visible, and an anti-correlation between $\delta^{18} \mathrm{O}$ and ${ }^{17} \mathrm{O}$-excess appears at Vostok and S2 that could be explained by a stratospheric input of water vapor. ${ }^{10} \mathrm{Be}$ values, measured in the same snow pit at $\mathrm{S} 2$, show a positive correlation with ${ }^{17} \mathrm{O}$-excess values (M. Baroni, personal communication, 2015), and thus give weight to this explanation. Such an effect is not visible at Dome $\mathrm{C}$ where no particular relationship between ${ }^{17} \mathrm{O}$ excess and $\delta^{18} \mathrm{O}$ is visible.

From the different types of snow in East Antarctica, we always observe a positive relationship between changes in surface temperature and change in $\delta^{18} \mathrm{O}$ of snow, even in the absence of precipitation. If confirmed by future studies, the correlation between $\delta^{18} \mathrm{O}$ of surface snow and temperature in the absence of precipitation in East Antarctica has strong importance for the interpretation of water isotopes in deep ice cores. Indeed, East Antarctica is characterized by a very small accumulation rate (even smaller during glacial periods); therefore post-deposition effects are expected to have a significant effect. Our findings suggest that post-deposition effects lead to a correlation between $\delta^{18} \mathrm{O}$ and temperature. To better understand the exchanges between surface snow 
and atmospheric vapor, and to assess their impact on the isotopic compositions, detailed models focusing on these interactions are needed. In the future, the development of models of post-deposition processes equipped with water isotopes may become the key to the quantitative interpretation of isotopes in ice cores.

Finally, from our data, we calculated a wide range of temporal slopes between $\delta^{18} \mathrm{O}$ and temperature $(0.14$ to $0.46 \%{ }^{\circ} \mathrm{C}^{-1}$, Table 2 ). They are in general significantly lower than the spatial slope of the $\delta^{18} \mathrm{O}$ vs. temperature relationship over Antarctica (0.8\%o, Lorius and Merlivat, 1977; Masson-Delmotte et al., 2008). Such results have important implications for the temperature reconstructions from deep ice cores in central Antarctica. Indeed, with a smaller $\delta^{18} \mathrm{O}$ vs. temperature slope, the $\delta^{18} \mathrm{O}$-inferred amplitude of past temperature changes is larger. This is in agreement with outputs of experiments performed with AGCM equipped with water isotopes. Indeed, the modeled temporal slopes between $\delta^{18} \mathrm{O}$ and temperature over the East Antarctic plateau, both at annual and glacial-interglacial scales, are generally smaller by up to a factor of 2 compared to the present-day spatial slope over Antarctica (Cauquoin et al., 2015b; Lee et al., 2008; Risi et al., 2010; Schmidt et al., 2007; Sime et al., 2008, 2009).

\section{The Supplement related to this article is available online at doi:10.5194/tc-10-837-2016-supplement.}

Acknowledgements. The research leading to these results has received funding from the European Research Council under the European Union's Seventh Framework Programme (FP7/20072013)/ERC grant agreement no. 306045. We are indebted to Michel Fily and Laurent Arnaud who organized the VANISH expedition and provided samples for this study. We would like to thank the ANR VANISH (ANR-07-VULN-013) for their support, as well as the IPEV programme SUNITEDC (1011). We also acknowledge the contribution of the PRIDE project funded by PNRA-MIUR and of the Russian Antarctic Expeditions. The snow samples from the transects including Syowa-Dome F were sampled by the Japanese Antarctic Research Expedition and the National Institute of Polar Research (NIPR), Tokyo, in the framework of the joint Japanese-Swedish IPY traverse. This research was partly supported by JSPS Postdoctoral Fellowships for Research Abroad and by JSPS KAKENHI grant number 26550013.

Edited by: M. Schneebeli

\section{References}

Altnau, S., Schlosser, E., Isaksson, E., and Divine, D.: Climatic signals from 76 shallow firn cores in Dronning Maud Land, East Antarctica, The Cryosphere, 9, 925-944, doi:10.5194/tc-9-9252015, 2015.

Barkan, E. and Luz, B.: Diffusivity fractionations of $\mathrm{H}_{2}{ }^{16} \mathrm{O} / \mathrm{H}_{2}^{17} \mathrm{O}$ and $\mathrm{H}_{2}^{16} \mathrm{O} / \mathrm{H}_{2}^{18} \mathrm{O}$ in air and their implications for isotope hydrology, Rapid Commun. Mass Spectrom., 21, 2999-3005, 2007.

Barkan, E. and Luz, B.: High precision measurements of ${ }^{17} \mathrm{O} /{ }^{16} \mathrm{O}$ and ${ }^{18} \mathrm{O} /{ }^{16} \mathrm{O}$ ratios in $\mathrm{H}_{2} \mathrm{O}$, Rapid Commun. Mass Spectrom., 19, 3737-3742, 2005.

Becagli, S., Proposito, M., Benassai, S., Flora, O., Genoni, L., Gragnani, R., Largiuni, O., Pili, S. L., Severi, M., Stenni, B., Traversi, R., Udisti, R., and Frezzotti, M.: Chemical and isotopic snow variability in East Antarctica along the 2001/02 ITASE traverse, Ann. Glaciol., 39, 473-482, 2004.

Casado, M., Landais, A., Masson-Delmotte, V., Genthon, C., Kerstel, E., Kassi, S., Arnaud, L., Picard, G., Prie, F., Cattani, O., Steen-Larsen, H.-C., Vignon, E., and Cermak, P.: Continuous measurements of isotopic composition of water vapour on the East Antarctic Plateau, Atmos. Chem. Phys. Discuss. doi:10.5194/acp-2016-8, in review, 2016.

Cauquoin, A., Jean-Baptiste, P., Risi, C., Fourré, E., Stenni, B., and Landais, A.: The global distribution of natural tritium in precipitation simulated with an Atmospheric General Circulation Model and comparison with observations, Earth Planetary Sc. Lett., 427, 160-170, 2015a.

Cauquoin, A., Landais, A., Raisbeck, G. M., Jouzel, J., Bazin, L., Kageyama, M., Peterschmitt, J.-Y., Werner, M., Bard, E., and Team, ASTER: Comparing past accumulation rate reconstructions in East Antarctic ice cores using ${ }^{10} \mathrm{Be}$, water isotopes and CMIP5-PMIP3 models, Clim. Past, 11, 355-367, doi:10.5194/cp-11-355-2015, 2015b.

Champollion, N., Picard, G., Arnaud, L., Lefebvre, E., and Fily, M.: Hoar crystal development and disappearance at Dome C, Antarctica: observation by near-infrared photography and passive microwave satellite, The Cryosphere, 7, 1247-1262, doi:10.5194/tc-7-1247-2013, 2013.

Charles, C. D., Rind, D., Jouzel, J., Koster, R. D., and Fairbanks, R. G.: Glacial-Interglacial changes in moisture sources for Greenland: Influences on the ice core record of climate, Science, 263, 508-511, 1994.

Ciais, P. and Jouzel, J.: Deuterium and oxygen 18 in precipitation: Isotopic model, including mixed cloud processes, J. Geophys. Res.-Atmos., 99, 16793-16803, 1994.

Craig, H.: Isotopic variations in meteoric waters, Science, 133, 1702-1703, 1961

Craig, H. and Lal, D.: The production rate of natural tritium, Tellus, 13, 85-105, 1961.

Dansgaard, W.: Stable isotopes in precipitation, Tellus, 16, 436468, 1964.

Delmotte, M., Masson, V., Jouzel, J., and Morgan, V. I.: A seasonal deuterium excess signal at Law Dome, coastal eastern Antarctica: A Southern Ocean signature, J. Geophys. Res.-Atmos., 105, 7187-7197, 2000.

Ekaykin, A. A.: Meteorological regime of central Antarctica and its role in the formation of isotope composition of snow thickness, 
Glaciology, Faculté de Géographie de Saint Pétersbourg, Saint Pétersbourg, 137 pp., 2003.

Ekaykin, A. A., Lipenkov, V. Y., Barkov, N. I., Petit, J. R., and Masson-Delmotte, V.: Spatial and temporal variability in isotope composition of recent snow in the vicinity of Vostok station, Antarctica: implications for ice-core record interpretation, Ann. Glaciol., 35, 181-186, 2002.

Ekaykin, A. A., Lipenkov, V. Y., Kuzmina, I. N., Petit, J. R., Masson-Delmotte, V., and Johnsen, S. J.: The changes in isotope composition and accumulation of snow at Vostok station, East Antarctica, over the past 200 years, Ann. Glaciol., 39, 569-575, 2004.

Ekaykin, A. A., Kozachek, A. V., Lipenkov, V. Y., and Shibaev, Y. A.: Multiple climate shifts in the Southern hemisphere over the past three centuries based on central Antarctic snow pits and core studies, Ann. Glaciol., 55, 259-266, 2014.

EPICA comm. members: Eight glacial cycles from an Antarctic ice core, Nature, 429, 623-628, 2004.

Fawcett, P. J., Ágústsdóttir, A. M., Alley, R. B., and Shuman, C. A.: The Younger Dryas termination and North Atlantic Deep Water formation: Insights from climate model simulations and Greenland ice cores, Paleoceanography, 12, 23-38, 1997.

Fourré, E., Jean-Baptiste, P., Dapoigny, A., Baumier, D., Petit, J.R., and Jouzel, J.: Past and recent tritium levels in Arctic and Antarctic polar caps, Earth Planet. Sc. Lett., 245, 56-64, 2006.

Franz, P. and Röckmann, T.: High-precision isotope measurements of $\mathrm{H}_{2}^{16} \mathrm{O}, \mathrm{H}_{2}^{17} \mathrm{O}, \mathrm{H}_{2}^{18} \mathrm{O}$, and the $\Delta^{17} \mathrm{O}$-anomaly of water vapor in the southern lowermost stratosphere, Atmos. Chem. Phys., 5, 2949-2959, doi:10.5194/acp-5-2949-2005, 2005.

Fujita, K. and Abe, O.: Stable isotopes in daily precipitation at Dome Fuji, East Antarctica, Geophys. Res. Lett., 33, L18503, doi:10.1029/2006GL026936, 2006.

Fujita, S., Holmlund, P., Andersson, I., Brown, I., Enomoto, H., Fujii, Y., Fujita, K., Fukui, K., Furukawa, T., Hansson, M., Hara, K., Hoshina, Y., Igarashi, M., Iizuka, Y., Imura, S., Ingvander, S., Karlin, T., Motoyama, H., Nakazawa, F., Oerter, H., Sjöberg, L. E., Sugiyama, S., Surdyk, S., Ström, J., Uemura, R., and Wilhelms, F.: Spatial and temporal variability of snow accumulation rate on the East Antarctic ice divide between Dome Fuji and EPICA DML, The Cryosphere, 5, 1057-1081, doi:10.5194/tc-51057-2011, 2011.

Gao, J., Masson-Delmotte, V., Yao, T., Tian, L., Risi, C., and Hoffmann, G.: Precipitation water stable isotopes in the South Tibetan Plateau: observation and modeling, J. Climate, 24, 3161-3178, 2011.

Gat, J. R.: Oxygen and hydrogen isotopes in the hydrologic cycle, Annu. Rev. Earth Planet. Sci., 24, 225-262, 1996.

Hoshina, Y., Fujita, K., Nakazawa, F., Iizuka, Y., Miyake, T., Hirabayashi, M., Kuramoto, T., Fujita, S., and Motoyama, H.: Effect of accumulation rate on water stable isotopes of near-surface snow in inland Antarctica, J. Geophys. Res., 119, 274-283, 2014.

Jouzel, J. and Merlivat, L.: Deuterium and oxygen 18 in precipitation: modeling of the isotopic effects during snow formation, $\mathrm{J}$. Geophys. Res., 89, 11749-11757, 1984.

Jouzel, J., Vimeux, F., Caillon, N., Delaygue, G., Hoffmann, G., Masson-Delmotte, V., and Parrenin, F.: Magnitude of isotope/temperature scaling for interpretation of central Antarctic ice cores, J. Geophys. Res.-Atmos., 108, 4361, doi:10.1029/2002JD002677, 2003.
Jouzel, J., Masson-Delmotte, V., Stiévenard, M., Landais, A., Vimeux, F., Johnsen, S. J., Sveinbjörnsdottir, A. E., and White, J. W. C.: Rapid deuterium-excess changes in Greenland ice cores: a link between the ocean and the atmosphere, Compt. Rendus Geosci., 337, 957-969, 2005.

Jouzel, J., Masson-Delmotte, V., Cattani, O., Dreyfus, G., Falourd, S., Hoffmann, G., Minster, B., Nouet, J., Barnola, J. M., Chappellaz, J., Fischer, H., Gallet, J. C., Johnsen, S., Leuenberger, M., Loulergue, L., Luethi, D., Oerter, H., Parrenin, F., Raisbeck, G., Raynaud, D., Schilt, A., Schwander, J., Selmo, E., Souchez, R., Spahni, R., Stauffer, B., Steffensen, J. P., Stenni, B., Stocker, T. F., Tison, J. L., Werner, M., and Wolff, E. W.: Orbital and millennial Antarctic climate variability over the past 800,000 years, Science, 317, 793-796, 2007.

Jouzel, J., Delaygue, G., Landais, A., Masson-Delmotte, V., Risi, C., and Vimeux, F.: Water isotopes as tools to document oceanic sources of precipitation, Water Resour. Res., 49, 7469-7486, 2013.

Kawamura, K., Parrenin, F., Lisiecki, L., Uemura, R., Vimeux, F., Severinghaus, J. P., Hutterli, M. A., Nakazawa, T., Aoki, S., Jouzel, J., Raymo, M. E., Matsumoto, K., Nakata, H., Motoyama, H., Fujita, S., Goto-Azuma, K., Fujii, Y., and Watanabe, O.: Northern Hemisphere forcing of climatic cycles in Antarctica over the past 360,000 years, Nature, 448, 912-916, 2007.

Krinner, G., Genthon, C., Li, Z.-X., and Le Van, P.: Studies of the Antarctic climate with a stretched-grid general circulation model, J. Geophys. Res.-Atmos., 102, 13731-13745, 1997.

Kurita, N.: Origin of Arctic water vapor during the ice-growth season, Geophys. Res. Lett., 38, L02709, doi:10.1029/2010GL046064, 2011.

Küttel, M., Steig, E., Ding, Q., Monaghan, A., and Battisti, D.: Seasonal climate information preserved in West Antarctic ice core water isotopes: relationships to temperature, large-scale circulation, and sea ice, Clim. Dynam., 39, 1841-1857, 2012.

Landais, A., Barkan, E., and Luz, B.: Record of $\delta^{18} \mathrm{O}$ and ${ }^{17} \mathrm{O}$-excess in ice from Vostok Antarctica during the last 150,000 years, Geophys. Res. Lett., 35, L02709, doi:10.1029/2007GL032096, 2008.

Landais, A., Barkan, E., Vimeux, F., Masson-Delmotte, V., and Luz, B.: Combined analysis of water stable isotopes $\left(\mathrm{H}_{2}^{16} \mathrm{O}, \mathrm{H}_{2}^{17} \mathrm{O}\right.$, $\mathrm{H}_{2}^{18} \mathrm{O}, \mathrm{HD}^{16} \mathrm{O}$ ) in ice cores, Physics of Ice Core Records II, Supplement Issue of Low Temperature Science, 2009.

Landais, A., Ekaykin, A., Barkan, E., Winkler, R., and Luz, B.: Seasonal variations of ${ }^{17} \mathrm{O}$-excess and d-excess in snow precipitation at Vostok station, East Antarctica, J. Glaciol., 58, 725-733, 2012a.

Landais, A., Steen-Larsen, H. C., Guillevic, M., Masson-Delmotte, V., Vinther, B., and Winkler, R.: Triple isotopic composition of oxygen in surface snow and water vapor at NEEM (Greenland), Geochim. Cosmochim. Acta, 77, 304-316, 2012b.

Lee, J.-E., Fung, I., DePaolo, D. J., and Henning, C. C.: Analysis of the global distribution of water isotopes using the NCAR atmospheric general circulation model, J. Geophys. Res.-Atmos., 112, D16306, doi:10.1029/2006JD007657, 2007.

Lee, J.-E., Fung, I., DePaolo, D. J., and Otto-Bliesner, B.: Water isotopes during the Last Glacial Maximum: New general circulation model calculations, J. Geophys. Res., 113, D19109, doi:10.1029/2008JD009859, 2008. 
Le Meur, E., Magand, O., Arnaud, L., Fily, M., Frezzotti, M., Mulvaney, R., Erbland, J., and Cavitte, M.. Snow accumulation pattern over the East Antarctic plateau from combined Ground Penetrating Radar measurements and shallow core analysis, The Cryosphere, in preparation, 2016.

Lin, Y., Clayton, R. N., Huang, L., Nakamura, N., and Lyons, J. R.: Oxygen isotope anomaly observed in water vapor from Alert, Canada and the implication for the stratosphere, P. Natl. Acad. Sci., 110, 15608-15613, 2013.

Lorius, C. and Merlivat, L.: Distribution of mean surface stable isotopes values in East Antarctica; observed changes with depth in coastal area, General assembly of the International Union of Geodesy and Geophysics, Grenoble, France, 1-18, 1977.

Luz, B. and Barkan, E.: Variations of ${ }^{17} \mathrm{O} /{ }^{16} \mathrm{O}$ and ${ }^{18} \mathrm{O} /{ }^{16} \mathrm{O}$ in meteoric waters, Geochim. Cosmochim. Acta, 74, 6276-6286, 2010.

Magand, O., Frezzotti, M., Pourchet, M., Stenni, B., Genoni, L., and Fily, M.: Climate variability along latitudinal and longitudinal transects in East Antarctica, Ann. Glaciol., 39, 351-358, 2004.

Masarik, J. and Beer, J.: An updated simulation of particle fluxes and cosmogenic nuclide production in the Earth's atmosphere, J. Geophys. Res., 114, D11103, doi:10.1029/2008JD010557, 2009.

Masson-Delmotte, V., Landais, A., Stievenard, M., Cattani, O., Falourd, S., Jouzel, J., Johnsen, S. J., Dahl-Jensen, D., Sveinsbjornsdottir, A., White, J. W. C., Popp, T., and Fischer, H.: Holocene climatic changes in Greenland: Different deuterium excess signals at Greenland Ice Core Project (GRIP) and NorthGRIP, J. Geophys. Res.-Atmos., 110, D14102, doi:10.1029/2004JD005575, 2005.

Masson-Delmotte, V., Hou, S., Ekaykin, A., Jouzel, J., Aristarain, A., Bernardo, R., Bromwich, D., Cattani, O., Delmotte, M., and Falourd, S.: A review of Antarctic surface snow isotopic composition: Observations, atmospheric circulation, and isotopic modeling, J. Climate, 21, 3359-3387, 2008.

Masson-Delmotte, V., Swingedouw, D., Landais, A., Seidenkrantz, M.-S., Gauthier, E., Bichet, V., Massa, C., Perren, B., Jomelli, V., Adalgeirsdottir, G., Hesselbjerg Christensen, J., Arneborg, J., Bhatt, U., Walker, D. A., Elberling, B., Gillet-Chaulet, F., Ritz, C., Gallée, H., van den Broeke, M., Fettweis, X., de Vernal, A., and Vinther, B.: Greenland climate change: from the past to the future, Wiley Interdisciplinary Reviews: Climate Change, 3, 427-449, 2012.

Mayewski, P. A. and Goodwin, I.: Antarctic's role pursued in global climate change, Eos T. Am. Geophys. Union, 80, 398-400, 1999.

Mayewski, P. A., Frezzotti, M., Bertler, N., van Ommen, T., Hamilton, G., Jacka, T. H., Welch, B., Frey, M., Dahe, Q., Jiawen, R., Simoes, J., Fily, M., Oerter, H., Nishio, F., Isaksson, E., Mulvaney, R., Holmund, P., Lipenkov, V., and Goodwin, I.: The International Trans-Antarctic Scientific Expedition (ITASE): an overview, Ann. Glaciol., 41, 180-185, 2005.

Meijer, H. A. J. and Li, W. J.: The use of electrolysis for accurate $\delta^{17} \mathrm{O}$ and $\delta^{18} \mathrm{O}$ isotope measurements in water, Isotop. Environ. Health Stud., 34, 349-369, 1998.

Motoyama, H., Hirasawa, N., Satow, K., and Watanabe, O.: Seasonal variations in oxygen isotope ratios of daily collected precipitation and wind drift samples and in the final snow over at Dome Fuji Station, Antarctica, J. Geophys. Res., 110, D11106, doi:10.1029/2004JD004953, 2005.
Neumann, T. A., Waddington, E. D., Steig, E. J., and Grootes, P. M.: Non-climate influences on stable isotopes at Taylor Mouth, Antarctica, J. Glaciol., 51, 248-258, 2005.

Pang, H., Hou, S., Landais, A., Masson-Delmotte, V., Prie, F., Steen-Larsen, H. C., Risi, C., Li, Y., Jouzel, J., Wang, Y., He, J., Minster, B., and Falourd, S.: Spatial distribution of ${ }^{17} \mathrm{O}-$ excess in surface snow along a traverse from Zhongshan station to Dome A, East Antarctica, Earth Planet. Sc. Lett., 414, 126133, 2015.

Petit, J. R., White, J. W. C., Young, N. W., Jouzel, J., and Korotkevich, Y. S.: Deuterium excess in recent Antarctic snow, J. Geophys. Res.-Atmos., 96, 5113-5122, 1991.

Petit, J. R., Jouzel, J., Raynaud, D., Barkov, N. I., Barnola, J. M., Basile, I., Bender, M., Chappellaz, J., Davis, M., Delaygue, G., Delmotte, M., Kotlyakov, V. M., Legrand, M., Lipenkov, V. Y., Lorius, C., Pepin, L., Ritz, C., Saltzman, E., and Stievenard, M.: Climate and atmospheric history of the past 420,000 years from the Vostok ice core, Antarctica, Nature, 399, 429-436, 1999.

Proposito, M., Becagli, S., Castellano, E., Flora, O., Genoni, L., Gragnani, R., Stenni, B., Traversi, R., Udisti, R., and Frezzotti, M.: Chemical and isotopic snow variability along the 1998 ITASE traverse from Terra Nova Bay to Dome C, East Antarctica, Ann. Glaciol., 35, 187-194, 2002.

Reijmer, C. H., van den Broeke, M. R., and Scheele, M. P.: Air parcel trajectories and snowfall related to five deep drilling locations in Antarctica based on the ERA-15 dataset, J. Climate, 15, $1957-$ 1968, 2002.

Risi, C., Bony, S., Vimeux, F., and Jouzel, J.: Water-stable isotopes in the LMDZ4 general circulation model: Model evaluation for present-day and past climates and applications to climatic interpretations of tropical isotopic records, J. Geophys. Res.-Atmos., 115, D12118, doi:10.1029/2009JD013255, 2010.

Risi, C., Landais, A., Winkler, R., and Vimeux, F.: Can we determine what controls the spatio-temporal distribution of d-excess and ${ }^{17} \mathrm{O}$-excess in precipitation using the LMDZ general circulation model?, Clim. Past, 9, 2173-2193, doi:10.5194/cp-9-21732013, 2013.

Ritter, F., Steen-Larsen, H. C., Werner, M., Masson-Delmotte, V., Orsi, A., Behrens, M., Birnbaum, G., Freitag, J., Risi, C., and Kipfstuhl, S.: Isotopic exchange on the diurnal scale between near-surface snow and lower atmospheric water vapor at Kohnen station, East Antarctica, The Cryosphere Discuss., doi:10.5194/tc-2016-4, in review, 2016.

Schlosser, E., Oerter, H., Masson-Delmotte, V., and Reijmer, C.: Atmospheric influence on the deuterium excess signal in polar firn: implications for ice core interpretation, J. Glaciol., 54, 117124, 2008.

Schmidt, G. A., Hoffmann, G., Shindell, D. T., and Hu, Y.: Modeling atmospheric stable water isotopes and the potential for constraining cloud processes and stratosphere-troposphere water exchange, J. Geophys. Res.-Atmos., 110, D21314, doi:10.1029/2005JD005790, 2005.

Schmidt, G. A., LeGrande, A. N., and Hoffmann, G.: Water isotope expressions of intrinsic and forced variability in a coupled ocean-atmosphere model, J. Geophys. Res.-Atmos., 112, D10103, doi:10.1029/2006JD007781, 2007.

Schneider, D. P., Steig, E. J., Ommen, T. D. v., Dixon, D. A., Mayewski, P. A., Jones, J. M., and Bitz, C. M.: Antarctic tem- 
peratures over the past two centuries from ice cores, Geophys. Res. Lett., 33, L16707, doi:10.1029/2006GL027057, 2006.

Schoenemann, S. W., Schauer, A. J., and Steig, E. J.: Measurement of SLAP2 and GISP $\delta^{17} \mathrm{O}$ and proposed VSMOW-SLAP normalization for $\delta^{17} \mathrm{O}$ and ${ }^{17}$ Oexcess, Rapid Commun. Mass Spectrom., 27, 582-590, 2013.

Schoenemann, S. W., Steig, E. J., Ding, Q., Markle, B. R., and Schauer, A. J.: Triple water-isotopologue record from WAIS Divide, Antarctica: Controls on glacial-interglacial changes in ${ }^{17} \mathrm{O}$ excess of precipitation, J. Geophys. Res.-Atmos., 119, 8741-8763, 2014.

Sime, L. C., Tindall, J. C., Wolff, E. W., Connolley, W. M., and Valdes, P. J.: Antarctic isotopic thermometer during a $\mathrm{CO}_{2}$ forced warming event, J. Geophys. Res., 113, D24119, doi:10.1029/2008JD010395, 2008.

Sime, L. C., Wolff, E. W., Oliver, K. I. C., and Tindall, J. C.: Evidence for warmer interglacials in East Antarctic ice cores, Nature, 462, 342-345, 2009.

Sokratov, S. A. and Golubev, V. N.: Snow isotopic content change by sublimation, J. Glaciol. 55, 823-828, 2009.

Steen-Larsen, H. C., Johnsen, S. J., Masson-Delmotte, V., Stenni, B., Risi, C., Sodemann, H., Balslev-Clausen, D., Blunier, T., Dahl-Jensen, D., Ellehøj, M. D., Falourd, S., Grindsted, A., Gkinis, V., Jouzel, J., Popp, T., Sheldon, S., Simonsen, S. B., Sjolte, J., Steffensen, J. P., Sperlich, P., Sveinbjörnsdóttir, A. E., Vinther, B. M., and White, J. W. C.: Continuous monitoring of summer surface water vapor isotopic composition above the Greenland Ice Sheet, Atmos. Chem. Phys., 13, 4815-4828, doi:10.5194/acp-13-4815-2013, 2013.

Stenni, B., Masson-Delmotte, V., Selmo, E., Oerter, H., Meyer, H., Röthlisberger, R., Jouzel, J., Cattani, O., Falourd, S., Fischer, H., Hoffmann, G., Iacumin, P., Johnsen, S. J., Minster, B., and Udisti, R.: The deuterium excess records of EPICA Dome $\mathrm{C}$ and Dronning Maud Land ice cores (East Antarctica), Quaternary Sci. Rev., 29, 146-159, 2010.

Stohl, A. and Sodemann, H.: Characteristics of atmospheric transport into the Antarctic troposphere, J. Geophys. Res., 115, D02305, doi:10.1029/2009JD012536, 2010.

Tindall, J. C., Valdes, P. J., and Sime, L. C.: Stable water isotopes in HadCM3: Isotopic signature of El Niño-Southern Oscillation and the tropical amount effect, J. Geophys. Res.-Atmos., 114, D04111, doi:10.1029/2008JD010825, 2009.

Town, M. S., Warren, S. G., Walden, V. P., and Waddington, E. D.: Effect of atmospheric water vapor on modification of stable isotopes in near-surface snow on ice-sheets, J. Geophys. Res., 113, D24303, doi:10.1029/2008JD009852, 2008.
Uemura, R., Matsui, Y., Motoyama, H., and Yoshida, N.: Deuterium and oxygen-18 determination of microliter quantities of a water sample using an automated equilibrator, Rapid Commun. Mass Spectrom., 21, 1783-1790, 2007.

Uemura, R., Matsui, Y., Yoshimura, K., Motoyama, H., and Yoshida, N.: Evidence of deuterium excess in water vapor as an indicator of ocean surface conditions, J. Geophys. Res.-Atmos., 113, D19114, doi:10.1029/2008JD010209, 2008.

Uemura, R., Barkan, E., Abe, O., and Luz, B.: Triple isotope composition of oxygen in atmospheric water vapor, Geophys. Res. Lett., 37, L04402, doi:10.1029/2009GL041960, 2010.

Uemura, R., Masson-Delmotte, V., Jouzel, J., Landais, A., Motoyama, H., and Stenni, B.: Ranges of moisture-source temperature estimated from Antarctic ice cores stable isotope records over glacial-interglacial cycles, Clim. Past, 8, 11091125, doi:10.5194/cp-8-1109-2012, 2012.

Van Hook, W. A.: Vapor pressures of the isotopic waters and ices, J. Phys. Chem., 72, 1234-1244, 1968.

Vimeux, F., Masson, V., Jouzel, J., Stievenard, M., and Petit, J. R.: Glacial-interglacial changes in ocean surface conditions in the Southern Hemisphere, Nature, 398, 410-413, 1999.

Werner, A. T.: BCSD Downscaled Transient Climate Projections for Eight Select GCM's over British Columbia, Canada, Victoria, BC, 63 pp., 2011.

Werner, M., Langebroek, P. M., Carlsen, T., Herold, M., and Lohmann, G.: Stable water isotopes in the ECHAM5 general circulation model: Toward high-resolution isotope modeling on a global scale, J. Geophys. Res.-Atmos., 116, D15109, doi:10.1029/2011JD015681, 2011.

Winkler, R., Landais, A., Sodemann, H., Dümbgen, L., Prié, F., Masson-Delmotte, V., Stenni, B., and Jouzel, J.: Deglaciation records of ${ }^{17} \mathrm{O}$-excess in East Antarctica: reliable reconstruction of oceanic normalized relative humidity from coastal sites, Clim. Past, 8, 1-16, doi:10.5194/cp-8-1-2012, 2012.

Winkler, R., Landais, A., Risi, C., Baroni, M., Ekaykin, A., Jouzel, J., Petit, J. R., Prié, F., Minster, B., and Falourd, S.: Interannual variation of water isotopologues at Vostok indicates a contribution from stratospheric water vapor, P. Natl. Acad. Sci., 110, 17674-17679, 2013.

Zahn, A., Franz, P., Bechtel, C., Grooß, J.-U., and Röckmann, T.: Modelling the budget of middle atmospheric water vapour isotopes, Atmos. Chem. Phys., 6, 2073-2090, doi:10.5194/acp-62073-2006, 2006. 